Portland State University

PDXScholar

\title{
Alienation Under the Rainbow: A Survey of Oregon Graduate Students
}

Robert Michael Travis

Portland State University

Follow this and additional works at: https://pdxscholar.library.pdx.edu/open_access_etds

Digitalrt of the Civic and Community Engagement Commons, and the Social Psychology and Interaction Commens

Neetonks know how access to this document benefits you. Logo

\section{Recommended Citation}

Travis, Robert Michael, "Alienation Under the Rainbow: A Survey of Oregon Graduate Students" (1980). Dissertations and Theses. Paper 2969.

https://doi.org/10.15760/etd.2967

This Thesis is brought to you for free and open access. It has been accepted for inclusion in Dissertations and Theses by an authorized administrator of PDXScholar. Please contact us if we can make this document more accessible: pdxscholar@pdx.edu. 
AN ABSTRACT OF THE THESIS OF Robert Michael Travis for the Master of Science in Sociology presented June 26, 1980.

Title: Alienation Under the Rainbow: A Survey of Oregon Graduate Students.

APPROVED BY MEMBERS OF THE THESIS COMMITTEE:
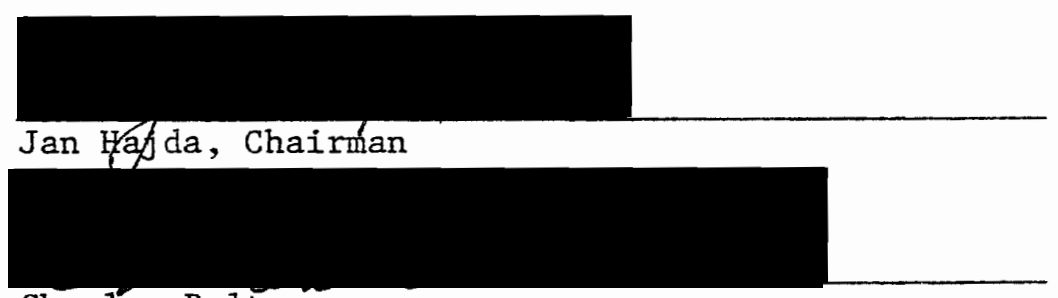

Charles Bolton

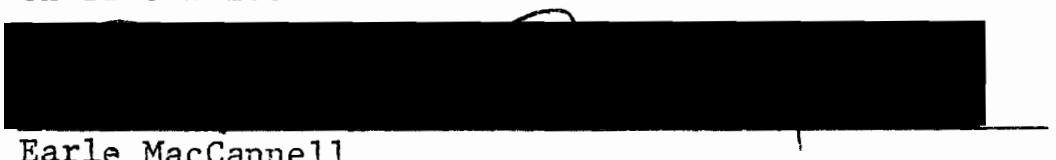

Nisbet's theory of alienation entails three propositions:

1) alienation is a unidimensional phenomenon; 2) alienation is a generalized phenomenon; and 3) power relations foster loss of community which engenders alienation. All three propositions were tested on a population of graduate students at a university in the Pacific Northwest.

A stratified random sample of 400 graduate students were contacted with a mail questionnalre in the spring of 1979: 80 percent responded after two follow-ups. Students were asked to indicate their perceptions on two alienation scales, alienation in politics and alienation in education. Statements about powerlessness 
and meaninglessness comprised the scales. Scale items were assessed using three methods: item-analysis, reliability, and criterion validity tests.

The results demonstrate that powerlessness and meaninglessness are not unidimensional, since, when operationalized, these concepts are negatively related. This also means that attempts to measure "the general syndrome of alienation" are likely to fail or end in error. Moreover, the findings indicate alienation is not a generalized phenomenon--that is, individuals are rarely alienated toward politics and education simultaneously. Some evidence from other studies suggests both these findings are not peculiar to the population surveyed.

Finally, although the minor propositions of Nisbet's theory of alienation were disconfirmed, the major proposition--the "1oss of community theme"--was confirmed. For instance, individuals who perceive that power characterizes their relations with national political institutions are more likely to feel alienated the more they sense, or experience, a loss of community in their lives. Still, some reservation concerning this finding is in order until better indicators of social bonds are developed and used to retest the theory. 
ALIENATION UNDER THE RAINBOW: A SURVEY

OF OREGON GRADUATE STUDENTS

by

ROBERT MICHAEL TRAVIS

A thesis submitted in partial fulfillment of the requirements for the degree of

\section{MASTER OF SCIENCE \\ in \\ Sociology}

Portland State University

1980 
TO THE OFFICE OF GRADUATE STUDIES AND RESEARCH:

The members of the Committee approve the thesis of Robert Michael Travis presented June 26, 1980.

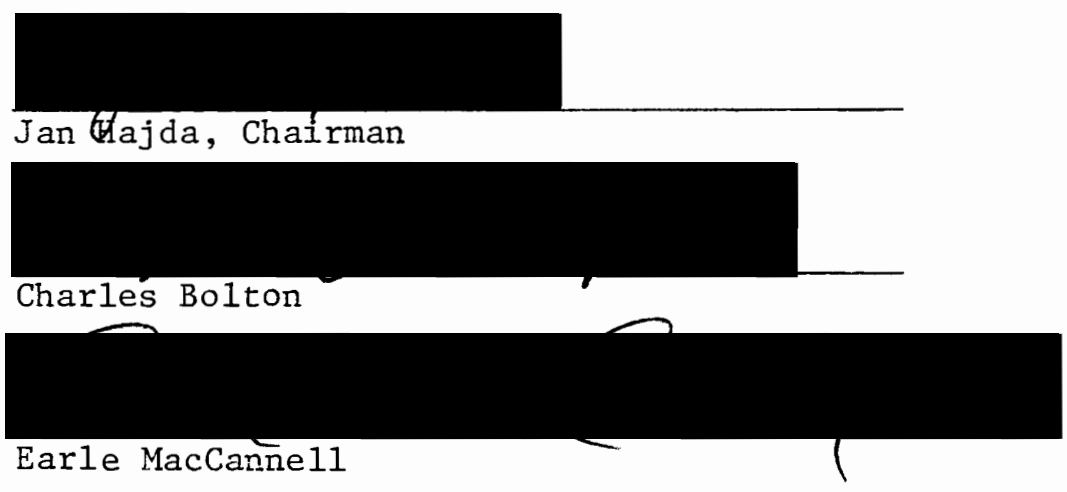

APPROVED;

Charles D. Bolton, Head, Department of Sociology

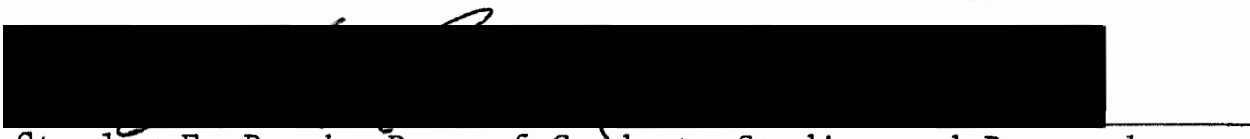

Stanley E. Rauch, Dean of Graduate Studies and Research 
"To find the truth, one must painstakingly eliminate the untrue."

--Sherlock Holmes (from Dressed to KilI) 


\section{ACKNOWLEDGEMENTS}

I wish to thank the members of my thesis committee, Jan Hajda, Chuck Bolton and Earle MacCannell, for their involvement and support. I am particularly thankful for the encouragement Jan has given me over the years to pursue research in the sociology of alienation and for his patient and accurate guidance. With Chuck, moreover, my debts are priceless: he has forced me over the years to tighten up the logic of my arguments and to attend to my ambitious starts with unfailing rigor. I am also indebted to them for the countless debates and conversations we enjoyed inside and outside of class.

I would also like to acknowledge the assistance the office of Institutional Research, Portland State University, gave me whenever I needed it. OIR provided me with numerous printouts and several special tabulations.

The University of Alaska, Fairbanks also should be thanked for providing me with a generous computer account and with excellent computer facilities. On more than one occasion, the personnel of the UAF Computer Center were more than helpful: their considerateness is appreciated.

Special thanks is also extended to the secretaries at the Institute of Social and Economic Research, University of Alaska, Eairbanks, who typed the earlier drafts of the thesis. 
Finally, particular thanks is accorded Carol Crawford, University of Michigan, Ann Arbor, who gave the final version of this thesis the look of class and who, on several occasions, was quite thoughtful. 
TABLE OF CONTENTS

PAGE

ACKNOWLEDGEMENTS $\ldots \ldots \ldots \ldots \ldots \ldots \ldots \ldots \ldots \ldots \ldots \ldots \ldots \ldots \ldots \ldots \ldots$ IV

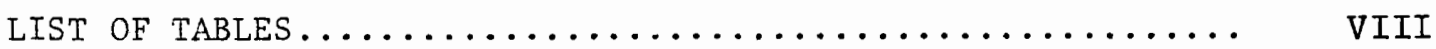

CHAPTER

I STATEMENT OF TUE PROBLEM.................... 1

Overview and Direction of Thesis.............. 1

Nisbet's Theory of Alienation: The Bellwether

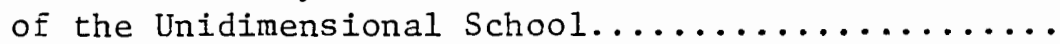

Power, Authority, and Loss of Community............

A Neoconservative Alternative to the

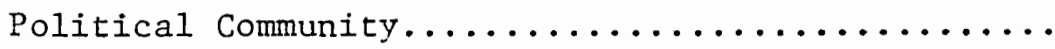

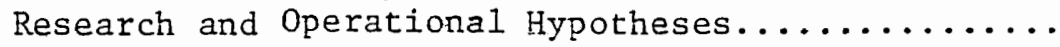

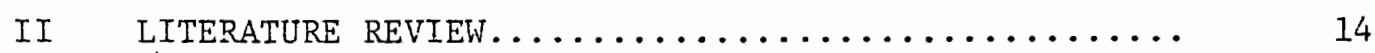

An Obituary for Alienation................... 14

Criteria for the Conceptualization of

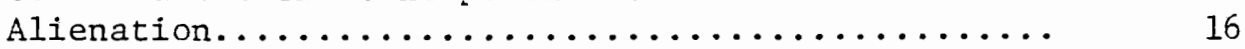

Alienation as a Unidimensional Concept............ 17

Alienation as a Discrete Concept............... 20

Alienation and the Generalization Hypothesis...... 24

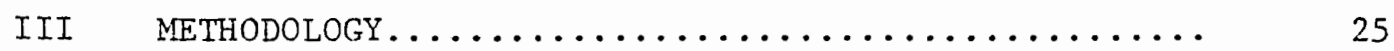

Research Design and Validity................. 25

Operationalization of Alienation............... 32

Reliability and Validity of the Alienation

Scale............................. 38

Operationalization of Perceptions of Community,

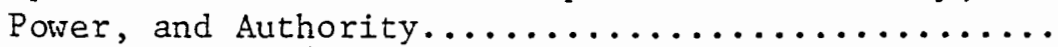

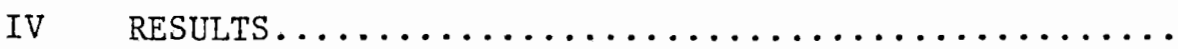

Powerlessness and Meaninglessness............. 50

Alienation in Politics and Education.............. 62

Alienation, Power Relations, and Loss of

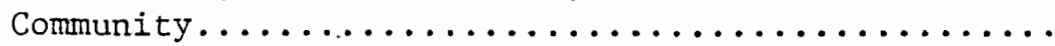




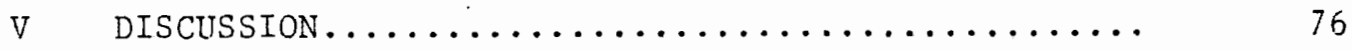

Relation of Findings to Previous Research........ 76

Theoretical Implications of Findings........... 82

Implications for Future Research............ 83

BIBLIOGRAPHY $\ldots \ldots \ldots \ldots \ldots \ldots \ldots \ldots \ldots \ldots \ldots \ldots \ldots \ldots$

APPENDIX............................... 92 


\section{LIST OF TABLES}

TABLE

PAGE

I Population and Sample Characteristics of Graduate and Postbaccalaureate Students at PSU, Winter-

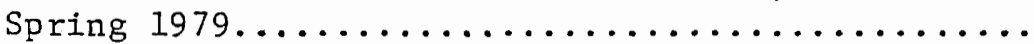

II Socio-Demographics of Two Populations of PSU

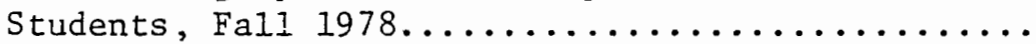

II Sample Characteristics of Graduate and Postbaccalaureate Students, Spring 1979...........

IV Responses of Graduate and Postbaccalaureate Students on Measures of Alienation............

$\mathrm{V}$ Item-Analysis of Measures of Alienation, Spring Survey: $1979 \ldots \ldots \ldots \ldots \ldots \ldots \ldots \ldots \ldots \ldots$

VI Criterion-Related Validity Test of Political Powerlessness Scale.....................

VII Criterion-Related Validity Test of Political Meaninglessness Scale...................

VII Criterion-Related Validity Test of Meaning-

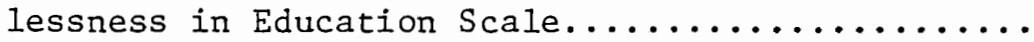

IX Criterion-Related Validity Test of Powerlessness in Education Scale...................

X Zero-Order Rank Correlations Between Powerlessness and Meaninglessness...............

XI Zero-Order Rank Correlations Between Powerlessness and Meaninglessness and the Proportion

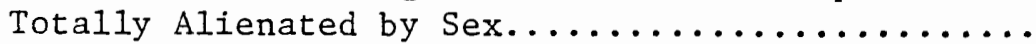

XII Partial Rank Correlations Between Political Powerlessness and Meaninglessness, Controlling for Selected Independent Variables (females)...... 
XIII Partial Rank Correlations Between Powerlessness and Meaninglessness in Education, Controlling for Selected Independent Variables (females).....................

XIV Partial Rank Correlations Between Political Powerlessness and Meaninglessness, Controlling for Selected Independent Variables (males).......

XV Partial Rank Correlations Between Powerlessness and Meaninglessness in Education, Controlling for Selected Independent

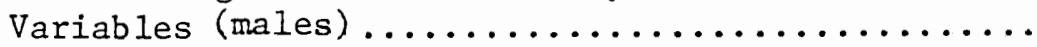

XVI Zero-Order Rank Correlations Between Institutional Powerlessness and Meaninglessness and the Proportion Totally Alienated by Sex.........

XVII Partial Rank Correlations Between Institutional Powerlessness and Meaninglessness, Controlling for Selected Independent Variables by Sex........

XVIII Zero-Order Rank Correlations Between Alienation and Loss of Community. and the Proportion Rootless by Perceptions of Power and Authority Relations..........................

XIX Characteristics of Students Who Evaluated the Fairness of Faculty Authority or Who Responded Don't know.........................

XX Partial Rank Correlations Between Alienation and Loss of Community, Controlling for Selected Independent Variables..............

XXI Kruskal-Wallis Analysis of Variance on Alienation and Loss of Community by Perceptions of

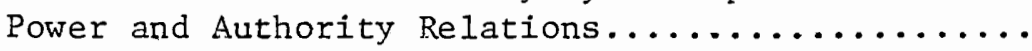

XXII Alienation and Loss of Community by Perceptions of Power and Authority Relations..............

XXIII Relationship Between Powerlessness and Meaninglessness Among American and French Workers, Controlling for Education, Occupation, and

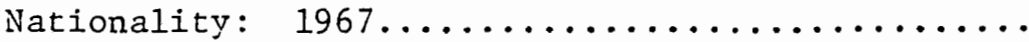


XXIV Trends in Political Efficacy Among Southern and Northern Negroes Relative to the White

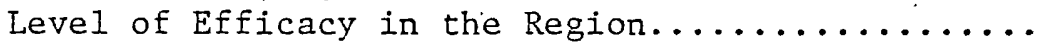




\section{CHAPTER I}

\section{STATEMENT OF THE PROBLEM}

OVERVIEW AND DIRECTION OF THESIS

Traditionally sociologists have studied alienation as a social problem (Thompson and Horton, 1960; Dean, 1965; Lieberson and Silverman, 1965; Radsford, 1968; Caplan and Paige, 1968) or in the context of social movements (Flacks, 1967; Morrison and Steeves, 1967 ; Bolton, 1972). Moreover, a few sociologists have dealt with alienation in organizations (Perlin, 1962; Seeman, 1963; Seeman and Evans, 1962). In contrast, psychologists have tended to study alienation as a personality trait (Trent and Craise, 1967; Watts et a1., 1969; Kenniston, 1971)

Yet apart from these foci, a few sociologists have researched alienation purely for its conceptual nature (Clark, 1959; Dean, 1961). These latter researchers have found that alienation is unidimensional, concluding that, although dimensions of alienation may appear isolable, types of alienation should be studied in concert rather than individually. But if this unidimensional approach is correct, more recent notions of alienation which conceive of dimensions of alienation as discrete phenomena appear in jeopardy (Barakat, 1970; Schacht, 1970; Wegner, 1975; Hajda and Travis, 1978). To date however, little research has issued out of the discrete 
school: it is the object of this study to fill that gap and empirically critique the unidimensional approach.

\section{NISBET'S THEORY OF ALIENATION: THE BELLWETHER OF THE UNIDIMENSIONAL SCHOOL}

Nisbet (1953) argues alienation is "one of the determining realities" of contemporary society. Although he does not clarify his conceptualization of alienation, Nisbet seems to regard it as unidimensional, involving both the "incomprehensible or fraudulent"-that is, powerlessness and meaninglessness. He contends Western civilization is mired in an "Age of Pessimism"--an age of uncertainty, of disintegration, and of spiritual aloneness. Modern society, having since the Middle Ages allowed the political state to usurp communal power and to render "functionless" intermediate associations, "tends by its very structure to produce the alienation, the disenchanted, the rootless, and the neurotic"(Nisbet, 1953:19). To him, then, alienation is a "conspicuous state of mind." Social institutions, such as the state, the corporation, the church, and the family, have become "increasingly difficult to give any part of one's self to"(Nisbet, 1953:ix).

Nisbet thus attempts to justify his argument that alienation is conspicuous, which also implies alienation is a generalized phenomenon, by linking the historical trend of powerlessness within the modern state with the trend of meaninglessness in modern primary and voluntary associations. Concentrated power, he argues, devalues the rich meanings and functions of interpersonal and communal life. 
As a result, the contemporary individual is lost and baffled and complains his relationships are no longer relevant to his needs.

- . it is becoming apparent that for more and more people [interpersonal] relationships are morally empty and psychologically baffling. . . The contemporary sense of alienation is most directly perhaps a problem in symbols and meaning, but it is also a problem in the institutional functions of the relationships that ordinarily communicate integration and purpose to individuals (Nisbet, 1953:52-53).

As such, Nisbet regards the problems of powerlessness and meaninglessness as intertwined: as the state becomes more powerful and cohesive, the role and authority of community in the lives of individuals diminishes, while more and more a "growing sense of isolation" and meaninglessness reverberates through their private lives.

\section{POWER, AUTHORITY, AND LOSS OF COMMUNITY}

Nisbet believes alienation results when allegiance to the family, community, and similar institutions are absorbed, or disrupted by the state. Essentially, Nisbet argues that when people cannot participate in community-based social authority relations embued with their consent, they become alienated. With the "erosion of natural authority" comes the "ideology of power," surfacing with the centralization of power.

Nisbet asserts power is external and based upon force: it arises when authority breaks down. Authority, on the other hand, is rooted in the statuses, functions, and allegiances of association. Although both power and authority involve constraint, authority differs from power, since the former is conditional ("based ultimately 
upon the consent of those under it"), while power is imposed and diminishes social solidarity. As regards power, Nisbet elaborates:

Where power is externalized or centralized . . . it is difficult for a true community to develop. Community thrives on self-help . . . and everything that removes a group from the performance of or involvement in its own government can hardly but help to weaken the sense of community . . . when external absorption of power and function threatens to remove the basis of community, leaving functionless and authority-less aggregates, what else but the social horde and alienation can be the result? (Nisbet, 1953, xvi-xvii).

For Nisbet then, authority relations are essential for social solidarity. Governance based upon authority is the principle of community self-rule. For people to feel secure and purposeful, he argues, they must be able to find fulfillment and autonomy in social groups. Primary and intermediate associations are the most important of these.

Yet the centralization and bureaucratization of contemporary society tends to diminish the importance of intermediate associations. Instead of families or guilds or local communities providing their members with education, material welfare, and protection, as was the case before the modern political state, the state assumes these functions. Yet as the state competed with primary associations for the allegiance of its members, individualism, impersonality, universalism, and moral fragmentation replaced the communalism, the kinship, the particularism, and the moral cohesion of medieval primary associations.

Of course, as the state centralized power, conflict characterized relations between the state and intermediate associations. After 
the Reformation though, power relations predominated. Individualism became essential to economic growth. For instance, the individual, not the family, became the subject of civil law, and property no longer was owned exclusively by the family. Moreover, power relations changed after the French Revolution from merely vertical (ruler to subject) to incorporate horizontal relations between individuals: rights and duties between individuals became dependent upon the state. But as individualism increased, social solidarity became problemmatic. Nisbet elaborates:

Behind the growing sense of isolation in society, behind the whole quest for community which infuses so many theoretical and practical areas of contemporary life and thought, lies the growing realization that the traditional primary relationships of men have become functionally irrevelant to our State and economy and meaningless to the moral aspirations of individuals. We are forced to the conclusion that a great deal of the peculiar character of contemporary social action comes from the efforts of men to find in large-scale organizations the values of status and security which were formerly gained in the primary associations of family, neighborhood, and church (Nisbet, 1953:49).

As such, Nisbet regards the disruption of authority relations, rather than the disorganization of the state, as the primary cause of lost community. What preoccupies him, however, is the prospect of the mass, haunted by "the specter of insecurity," disheveled by personal alienation, and having lost a sense of community, seeking new community by political means. It is his contention the political state is incapable of engendering new contexts of intermediate associations but rather capable of eradication. He warns, seeking community through politics has more often led to the total community -totalitarianism. 


\section{A NEOCONSERVATIVE ALTERNATIVE TO THE POLITICAL COMMUNITY}

Freedom for equality. This catch-phrase, if you will, seems to characterize Nisbet's delineation of the change from a society of free intermediate associations to a society of equal individuals. In short, as the modern political state disrupted the medieval society of associations, where the group was free to regulate itself, freedom was exchanged for equality. Authority within primary associations, Nisbet argues, lost its persuasiveness. as the social bond, as individuals became the focus of law. So atomized, individuals identified with the political community, hailing it for its redemptive power in freeing the individual from traditional ties and burdens.

In payment, of course. for freedom from the past, Nisbet asserts the state inculcated in individuals the necessity that allegiance to the state must supercede all other relations. Standardization of education, centralization of power, and the nationalization of identity facilitated this modern mass conversion--a conversion that accelerated after the French Revolution. Regarding this process, Nisbet concludes:

. . the single most decisive influence upon Western social organization has been the rise and development of the centralised territorial State. . . The State has risen as the dominant institutional force in our society and the most evocative symbol of cultural unity and purpose (Nisbet, 1953:98-99).

To be sure, Nisbet contends the "state is power:" it has successfully parlayed its original role as an organization for warfare for one where power is maximized in the name of social welfare. Such a transformation meant citizens would be independent of their 
fellow men and thus "absolutely dependent" on the state. Mass society resulted. The great danger is that "totalitarian regimes . . . are always preceded by mass movements" (Nisbet, 1953: 194). Consequently, if organized minorities are non-existent, Nisbet believes the total community of the state is more apt to realize itself. Nisbet elaborates:

Totalitarianism has been well described as the ultimate invasion of human privacy. But this invasion of privacy is possible only after the social contexts of privacy-family, church, association, have been atomized. The political enslavement of man requires the emancipation of man from all authorities and memberships (Nisbet, 1953:202).

Therefore, Nisbet, believing liberalism is imbedded with and confused over the rhetoric of freedom and power that helped create mass society, proposes a neoconservative alternative to the political community: a new philosophy of laissez-faire democracy. This neoconservatism essentially regards the association, not the individual, as the foundation of democracy: the state emerges as but one of the associations people belong to, not the ultimate or primary one. For without strong intermediate associations, "the State with the power to do things for pecple has the power to do things to them" (Nisbet, $1953: 258$ ).

Neoconservatism, moreover, assumes that freedom results not from the concentration of power for the new society, but upon the diversification and decentralization of power. The only safeguard against power is rival power. In short, Nisbet argues the decentralization of administration is "absolutely indispensible" to democracy; otherwise people will "become victims of the creeping 
totalitarianism inherent in administrative monopoly and centralization" (Nisbet, 1953:273). Only in small groups and small communities can institutions be framed to human scale, can purposive action thrive. Nisbet expounds :

To create the conditions within which autonomous individuals could prosper, could be emancipated from the binding of kinship, class and community, was the objective of the older laissez-faire. To create conditions within which autonomous groups may prosper must be, I believe, the prime objective of the new laissez-faire (Nisbet, 1953:278).

\section{RESEARCH AND QPERATIONAL HYPOTHESES}

To be sure, as one scientist notes, an "hypothesis is only a supposition" (Beveridge, 1950). Yet there are two kinds of suppositions: theoretical and operational. Theoretical suppositions, or research hypotheses, are conceptual in nature and thus formulated in theoretical referents (concepts, causality). On the other hand, operational suppositions, or hypotheses, are derivative in nature, being formulated in operational referents (variables, association):. Thus while the research hypothesis is derived from theory for verification, the operational hypothesis is the only one actually tested.

With regard to Nisbet's theory of alienation, which is a central critical focus of this thesis, at least three research hypotheses are derivable:

1) Alienation is unidimensional.

2) Alienation is a generalized phenomena.

3) Alienation results from loss of community in institutions where power, not authority, relations predominate. 
The first research hypothesis is derived from Nisbet's contention that alienation involves the "incomprehensible, or fraudulent." But as Seeman (1959) has shown, the incomprehensible implies a state of meaninglessness---where the individual is unclear as to what he ought to believe. Moreover, Hajda and Travis (1978) argue that to concelve of authority as fraudulent involves a state of powerlessness-where "powerlessness implies, first, a feeling of wrongness about having no choice." They assert:

Illegitimate control . . rests on accumulation of power, bestowed and exercised according to rules and principles which subordinates do not accept and the rulers proclaim but surreptitously disrespect (Hajda and Travis, 1978:2-3).

As such, it seems clear that Nisbet implies both powerlessness and meaninglessness when speaking of alienation. This entailment is evident in his emphasis that alienation results when power usurps authority and that the modern social order invites apathy. Therefore, if both powerlessness and meaninglessness characterize the alienated individual, then these types of alienation can be regarded as more similar than dissimilar and thus unidimensional. Subsequently, one operational hypothesis true to this assumption is:

\section{Operational Hypothesis I}

The more powerlessness, the more meaninglessness.

Of course, the argument might arise how can powerlessness and meaninglessness be considered separate percepts, when the theory regards them as unidimensional. This argument, however, is loaded down with sophistry, since in testing a theory one does not regard 
its suppositions as true until so proven. Therefore, to treat powerlessness and meaninglessness as unidimensional would be, at this point, begging the question.

The second research hypothesis, however, is implied, in part, by Nisbet's conceptualization of alienation: that is, for large numbers of people ". . alienation is a conspicuous state of mind" (Nisbet, 1953:ix). He seems to regard not only alienation, but its generalized nature, as self-evident. To support this presupposition Nisbet argues the decline in community has created "masses of helpless, bewildered individuals" who reflect the "atomization of personality" brought on by the tenuousness of social ties (Nisbet, 1953:14-15). Middle-class society, he argues, tends by its very structure to create the alienated, the rootless, and the neurotic. Such a society, Nisbet espouses, portends even more harm because the middle-class continues to allow state centralization and economic development to perpetuate a philosophy of "abstracted individualism." This philosophy conceives of the individual out of the context of commity bonds, insuring "success" for the individual, profits for the economy, and control for the state. Nisbet elaboratas:

The point is that with the decline in the significance of kinship and locality, and the failure of new social relationships to assume influences of equivalent evocative intensity, a profound change has occurred in the very psychological structure of society (Nisbet, 1953:69).

Thus, in his contention that dislocations in the functions of and allegiance to intermediate associations have affected countless persons, with the majority of individuals unattached to voluntary 
associations, Nisbet clearly implies alienation permeates the web of society. If the root of the problem is centralization, bureaucratization, and weak or non-existent associations, then the result is a disenchanted psyche, magnified to mass proportions. As such, what is to stop disenchantment and alienation from spilling over from one institution to another? Healthy voluntary and intermediate associations, of course. But if there are none, so to speak, then clearly alienation must be a generalized phenomena. The logic of Nisbet's theory of alienation entails no less: if an individual is alienated in one institution, that individual is very likely alienated in another. Subsequently, one operational hypothesis incorporating the logic of this argument is:

Operationa1 Hypothesis II

The more alienation in politics, the more alienation in education. Finally, the third research hypothesis is central to Nisbet's theory of alienation. He argues "community is the essential context" for studying alienation. Accordingly, social function and social authority "are the two supports upon which along community . . can exist and influence its members" (Nisbet, 1953:xii-xiii). But modern society has witnessed the "erosion of natural authority" in social institutions (the family, the university, the church). The functions of these institutions have been absorbed "chiefly by the state," where centralization and bureaucracy separate the individual from involvement in his own governance. Nisbet expounds:

Apart from authority there can be no really vital social relationship in society; this is as true in the family as it is in the university or the church. It is 
power, not authority, that seeks homogeneity, regimentation, and the manipulated articulation of parts by heirarchies of administrators (Nisbet, 1953:xiv).

Thus, for life to be meaningful, the communal relationships-those relations that integrate the individual into society--must have relevance and serve more than a nominal purpose. To be meaningful, Nisbet argues, these communal relations must arise out of authority. Indeed authority--the principle of governance by the consent of the governed--legitimizes communal relations. Consequently, as the community allows the ethic of participation to prevade its relations, the symptom of impersonal power, alienation, wanes.

Yet, if an individual participates in one institution suffused with authority and another impeded by power, then it seems reasonable to expect that individual will more likely be alienated in the context of power relations and that this alienation will be positively related to loss of community. For as Nisbet asserts, the principal strategy of institutions based on power relations, like the state, is to make the individual the solitary, complete unit and the state the sole association. The goal of centralized power is "to reduce in number and influence the intermediate social authorities" (Nisbet, 1953:252). Thus institutions predicated on power relations practice cultural nihilism: in power relations all personal interests are subordinate to allegiance to the sovereign institution. Nisbet extends this argument to the total state:

The masses are fundamental to the establishment of totalitarian society.... What is crucial in the formation of the masses is the atomization of all social and cultural relationships within which human beings gain 
their normal sense of membership in society. The mass is an aggregate of individuals who are insecure, basically lonely, and ground down, either through decree or historical circumstance, into mere particles of social dust (Nisbet, 1953:198-199).

Although Nisbet's depiction of power relation is extreme, it seems clear power relations engender loss of community and that one consequent of this process is alienation. Therefore, one operational hypothesis reflecting this theory of alienation is:

\section{Operational Hypothesis III}

In power relations, the more loss of community, the more alienation.

Conversely, in authority relations, experiencing more loss of community should not be positively associated with alienation, if Nisbet's theory were correct. Yet since this study takes only a "snap-shot" view of respondents, the theoretical causal link between power, loss of community, and alienation cannot be tested. Operational Hypothesis III, therefore, represents a weaker test. But if Nisbet's theory of alienation is invalid, this weaker test should be capable of disconfirmation, since the weaker hypothesis would necessarily follow if the causal hypothesis were true. Finally, the alternative to each operational hypothesis is that the null is not the case--the position this researcher favors. 
CHAPTER II

LITERATURE REVIEW

AN OBITUARY FOR ALIENATION

Lee (1973) argues that since "alienation has become the allexplaining catchword of the hour," it should be entirely abandoned as a concept rather than clarified. Essentially, his argument entails alienation is misused by two dominant groups: (1) "formula-peddling counselors,", who seek to encapsulate for patients their "estrangement from others, from work, from place, and even from self" (Lee, 1973: 122); and (2) social-order theorists, who seek to describe the systematic separation of society from its members. Lee charges that both usages are imbued with unscientific value-orienations. He elaborates:

Thus, "alienation" in one sense is a way of convincing individuals that they should depend upon the formulapeddling counselors. In another sense, it unconsciously or subconsciously becomes a device for persuading an individual that he alone or even working with others can do nothing worth-while about his social situation (Lee, 1973:123).

As such, Lee concludes alienation "tends to carry a judgment from one social viewpoint" (Lee, 1973:123). He notes psychological and systemic usage emphasizes static conceptions of alienation, ignoring the process of alienation itself, while also particularizing social problems. The solution, proposes Lee, is to apply instead 
terms like "relative isolation," "relative deprivation," and "marginality," since he considers them more scientific--in that they can be precisely defined, avoiding the "speculative, undefinable, and value-charged" quality of the term alienation.

In reply to Lee, it can be argued: 1) that he begs the question when charging some usage of alienation is deplorable, therefore all usage of alienation is deplorable (unscientific); 2) that he falsely assumes all systemic conceptions of alienation entail status quo rationalization of the social order (clearly Conflict and Ambivalent theories do not); and 3 ) that he falls to distinguish between conceptual definitions, their operationalizations, and the methods employed to study them--that is, even if conceptions are processoriented, they can be rendered static through measurement techniques. As such, Lee seems oblivious to studying how methods shape theories, assuming naively that theoretical conceptions always shape methods. Nonetheless, Lee should be appreciated for pointing out that static conceptions of alienation are inadequate. But to follow him, throwing out allenation for "relative isolation," "relative deprivation," and "marginality," seems just as inadequate. For all three states may not reflect alienation at all (if alienation is generally conceived as some form of personal disaffiliation from social institutions), since relative isolation may be temporarily sought after (as with graduate students giving up free time to pursue studies more thoroughly), while relative deprivation may engender social cohesion (as with upwardly mobile minorities gaining entrance into middle-class America), while marginality may be prized in itself 
(as with social scientists who "protect" their observer status apart from the groups they study). Consequently, substituting these terms for alienation does not clear up the "vagueness" about alienation: rather, these terms increase such vagueness threefold.

CRITERIA FOR THE CONCEPTUALIZATION OF ALIENATION Fischer (1976) concurs with Lee that alienation is "the most frequently misused, abused, and misconstrued term in sociology." Yet unlike Lee, Fischer emphasizes "the gulf between the 'alienations' of the philosopher-theoreticians and the 'alienations' of the empiricists." As such, Fischer suggests five criteria for conceptualizing alienation:

1) "it should be a variable attribute of people," implying the concept be "operationalizable and measurable;"

2) "it should refer to one class of phenomena, and only one," that is, "it should not be synonymous with, nor reducible to simpler terms;"

3) it "should be fruitful, useful in and suggestive of empirical relationships;"

4) the conceptualization "should be consistent with, if not absolutely true to, its philosophical sources;" and

5) the conceptualization "should allow incorporation of as much as possible of the better existing empirical research" (Fischer, 1976:36-37).

Subsequently, Fischer argues "Marx's introduction of 'human essence' into alienation conceptualization is damaging:" it fails since "any violation of 'human nature' must be alienation." Conceiving of alienation this broadly, moreover, does not distinguish it from frustration. Thus, Fischer concludes Marxian alienation "fails to meet the criterion (2) of being a distinctive concept." 
Yet in redefining alienation, Fischer relies upon Hegel and Feuerbach--their notions of externalization, or objectification, (whereby people act upon the world, creating entities which act back upon them). Fischer offers this definition and elaboration:

Alienation is the state in which the actor fails to perceive a positive interdependence between himself and social relationships or other objectifications. . . Alienation is not a free-floating psychic state. It is alienation from something. The stronger and more interesting empirical results occur when that 'something' is specified: work, political affairs, school achievement, social relationships, etc. (Fischer, 1976:43-44).

\section{ALIENATION AS AN UNIDIMENSIONAL CONCEPT}

Aside from the theoretical work of Nisbet, the unidimensional school of thought has produced little theoretical discussion on the nature of alienation. Instead, most of the work out of the unidimensional school has been empirical rather than theoretical. It is perhaps for this reason, though, that the unidimensional conceptualization of alienation has become well-known: some contemporary scholarly journals, particularly the American Sociological Review (where much of the school's work has been published), tend to favor empirical rather than purely analytic work.

Nevertheless, researchers out of this school not only take it for granted that all types of alienation have a unidimensional core meaning, but that the existence of such a core meaning indubitably links types of alienation empirically (Clark, 1959; Dean, 1961; Middleton, 1963; Neal et al., 1976). That is, given the fact different concepts of alienation share some common meaning, it is believed, and in fact "evidence" is put forth, that concepts of 
alienation, such as powerlessness and meaninglessness, are positively correlated. Consequently, the implication is that the fundamental diversity of types of alienation is for the most part de trop, since the supposed distinctiveness of types of alienation is claimed to be empirically slight.

Nevertheless, arguments about the empirical rigor of such research temporarily aside, the notion that types of alienation differ in nuance only seems rather far-fetched. On the one hand, it is affirmed that at least five distinct types of alienation exist: powerlessness, meaninglessness, normlessness, social isolation, and self-estrangement. While on the other hand, it is "empirically verified" that most of these concepts are highly and positively correlated. If there were once a need to differentiate between the central sociological notions of alienation, the work out of the unidimensional school demonstrates that such distinctions are noticeable, but not great and therefore, by implication, superfluous. Yet given this entailment what remains far-fetched is that, except for Clark (1959) and Middleton (1963), unidimensional researchers are either silent about or opposed to the simplification of alienation conceptualizations into fewer schema (Dean, 1961; Neal et a1., 1976). For instance, Dean (1961), seeking "to determine whether Alienation may be considered a general syndrome or whether the various components are somewhat discrete" (Dean, 1961:756), studied powerlessness, normlessness, and social isolation in an Ohio city. He reported intercorrelations between these types of alienation ranged from .41 to $.67(\mathrm{~N}=384)$ and suggests: 
It is quite feasible to consider the sub-scales as belonging to the same general concept. However, there appears to be enough independence among the sub-scales to warrant treating them as independent variables

(Dean, 1961:756).

But perhaps the main reason why Dean refuses to support a conceptual simplification of alienation is that he is firm in his belief that "Seeman has brought order out of chaos with his five-fold classification" (Dean, 1961:754). Ironical1y, Dean applauds this "five-fold classification" as an achievement over the times when researchers used to implicitly employ "several nuances of meaning" to denote alienation.

On the other hand. Middleton (1963), after hypothesizing "the different types of allenation are highly correlated with one another" (Middleton; 1963:973), surveyed 300 Blacks and Whites in a sma11 Florida town, reporting a correlation of .58 (Yule's Q) between powerlessness and meaninglessness. He also found a high coefficient of reproducibility $(.90)$ between such measures as powerlessness, meaninglessness, normlessness cultural estrangement, and social estrangement and concludes:

Although these five types of alienation may be distinct on a conceptual level, there is apparently an underlying unity. Studies employing a measure of generalized alienation thus may be feasible (Middleton, 1963:975).

Clark (1959), moreover, carries the empiricism of the unidimensional school to its logical, if not viable, conclusion. He discerns the "isolable feature" of all types of alienation as the individual's lack of power to eliminate the discrepancy between actual and "should-be" roles. He argues, therefore, "a measure of alienation 
must be a measure of the discrepancy between the power man believes he has and what he believes he should have--his estrangement from his rightful role" (Clark, 1959:849). This entails powerlessness underlies all types of alienation, even itself--an argument that contains a curious metaphysical predicament. Nonetheless, Clark notes powerlessness and belonginglessness (perhaps a "far from completely adequate" measure of meaninglessness) are highly and positively intercorrelated, concluding that researchers should devote further efforts "to. the development of a measure of the more general dimension of alienation in society" (Clark, 1959:852).

More recently, Neal et al. (1976) studied alienation within married couples of childbearing years $(\mathrm{N}=365$ couples $)$. Apart from their illumination of the separability of types of alienation among husbands and wives (that is, a single dimension of alienation is rarely generalized within couples), they observed positive correlations of .53 and .52 (Pearson's $r$ ) for wives and husbands between powerlessness and meaninglessness. Subsequently, they conclude ". . either that the problems of prediction and control are highly interrelated for family events or that we have not adequately maintained an analytical separation between the two in our scale construction" (Neal' et al., 1976:398).

\section{ALIENATION AS A DISCRETE CONCEPT}

Unlike the unidimensional school, the discrete school of thought has produced more theoretical than empirical work. Part of the reason may be reactive: since the unidimensional school dominated 
the field for so long, it may well be those in the discrete school saw the need to clear the air and issue correctives, so future research would avoid the operational distortions of the past.

For instance, Fischer (1976) attacks the common unidimensional methodology of measuring alienation as if it were "a feeling that 'the world is going to hell in a basket'," as Srole (1956) does in his once-popular alienation scale. Moreover, Fischer emphasizes that "to use alienation in a global manner" is meaningless, since "alienation takes on meaning as an attribute of an individual only within the context of specified relationships." The researcher should always ask: "What conditions produce alienation?" As such, he advises social psychologists to study "which situations generate alienation across a variety of people," instead of concentrating on the familiar problem of "which sorts of individual traits" predispose individuals to alienation.

Wegner (1975) essentially agrees with Fischer, as the former argues "attempts to understand discontent in specific social contexts, such as student alienation, . . should be more fruitful than approaching alienation as an orientation toward the total society" (Wegner, 1975:172). He also thinks "alienation is a response to a specific social context" and conceptualizes it thus:

Alienation is a negative orientation involving feelings of discontent and cynical beliefs toward a specific context. . . Alienation is disenchantment directed toward a social context which has its source in a discrepancy between an individual's characteristics and the structural conditions he faces in that context (Wegner, 1975: 177-178). 
Clearly then, Wegner disagrees with Nisbet and likewise Marx that alienation pervades the social system for each actor, emphasizing instead the notion of "discrepancy:" or disjunction, as do Hajda and Travis (1978). Wegner contends alienation theorists too often posit "a single or a few sources" of alienation, superimposing such upon all situations. He calls for a "two-stage" study of alienation, where researchers first examine different contexts, then focus upon the characteristics of persons alienated in whatever context.

Bolton (1972), after studying alienation among various peace groups, argues "situational factors, of both structural and episodic origin, play an important role in shaping action." Yet he modifies the context-specific approach by pointing out:

- . people are not thrust into situations at random. A person selects and is selected for situations in part on the basis of his presumed social-psychological orientations (Bolton, 1972:538).

Moreover, in comparing peace-group members to non-members, Bolton found that: (1) the more politically-active peace-group members felt less powerlessness than the less politically-active nonmembers; (2) the more active group felt less meaninglessness than the less active non-members: (3) among less active non-members meaninglessness and powerlessness appeared positively correlated, while among more active peace-group members meaninglessness and powerlessness appeared negatively correlated; (4) the less active felt less isolation and less normlessness than the more active; and (5) the more radical activists expressed much less powerlessness but much more meaninglessness than any other group. Consequently, Bolton concludes 
"normlessness, isolation, and meaninglessness all increase with degree of radical activity, while powerlessness decreases as radicalism increases" (Bolton, 1972:553). This suggests the sectarian nature of radical groups intensifies alienation and partially explains "the extreme alienation of radical activists." To be sure, Bolton's findings modify the unidimensional notion that powerlessness and meaninglessness are invariably positively correlated.

Finally, Schacht (1970) asserts the origin and, especially, the character of the dimensions of alienation are so considerably separate that the unidimensional argument is implausible. "Characterization of them in this fashion implies a degree of interrelatedness which they quite obviously lack" (Schacht, 1970:175). Schacht elaborates:

The intelligent voter confronted with a meaningless choice of candidates, the apathetic slum dweller, the student activist who distrusts those in power, the average citizen who finds social and economic events incomprehensible, and the dropout from society have in common a feeling of remoteness of some sort from some aspect of the socio-politico-economic world. But the origin and character of their separations from it differ so considerably that these separations cannot plausibly be viewed as dimensions of a single syndrome (Schacht, 1970:175).

Consequently, Schacht argues that should sociologists persist in treating alienation as a general syndrome, having a unidimensional meaning across the various types, the term "alienation" could not serve to denote a multidimensional concept at all. Rather the different types of alienation have only "a certain formal similarity."

Used in this way, it [alienation as a general concept] would function neither as a concrete descriptive term nor as a theoretical term, but rather as a general, 
nontheoretical classificatory term, analogous

to 'separation' (Schacht, 1970:175).

As such, the unidimensionality of all types of alienation can only be a vacuous conceptualization.

ALEINATION AND THE GENERALIZATION HYPOTHESIS

Seeman (1967) found the "generalization hypothesis" invalid. The "generalization hypothesis," in part, holds that "the lack of control in work leads to a sense of low control in political and social affairs." Seeman borrowed from Blauner's work in American factories, applying similar questions to Swedish workers, and found the correlation between powerlessness and work alienation to be only .05. No statistically significant differences existed between those feeling high work alienation and those feeling low work alienation when powerlessness was controlled for. Thus, Seeman lends credence to the context-specific, or discrete school of thought, approach for studying alienation.

On the other hand, Thompson and Horton (1960) assert that "political alienation is associated generally with lack of institutionalized power," with professionals and managers--the "arrived"-expressing less alienation than the "not arrived"--the young--and the "has-beens"--the elderly. If they are correct, it may mean the "differential distribution of power in the community"--more precisely, in the occupational roles--influences a pervasive sense of alienation, the kind Nisbet argues exists in modern society. 
CHAPTER III

METHODOLOGY

RESEARCH DESIGN AND VALIDITY

A random sample of 400 graduate students at Portland State University was conducted with mail questionnaires in the spring of 1979. Only students with U.S. citizenship were sampled--to avoid confounding cultural differences. An 80 percent response rate was obtained with two follow-ups, yielding a total of 311 respondents. $^{1}$ Since the sample was drawn from a known finite population of students enrolled at PSU in the winter of 1979, demographic data were readily available, making it possible to check the reliability of the survey data, as Kerlinger (1973) suggests.

With the exception of race, the sample and population correspond within 2 percentage points on such factors as sex, age, and academic status (Table I). Unfortunately, the sample underrepresents non-whites by a 7 percentage point difference. Moreover, results from a random sample of non-respondents indicate perhaps 40 percent of non-respondents did not vote in the 1976 Presidential election

$I_{\text {While the questionnaire response rate was high, the "no }}$ answer" rate for questions was generally low. For example, 83 percent of respondents answered every item on the questionnaire. But regarding the 17 percent with at least 1 "no answer," 65 percent $(N=54)$ only refused to answer 1 question, while only 19 percent refused to answer 3 or more questions. This means "missing data" on variables rarely was much of a problem during the analysis. 
TABLE I

POPULATION AND SAMPLE CHARACTERISTICS OF GRADUATE AND POSTBACCALAUREATE STUDENTS AT PSU, WINTER-

SPRING 1979 (U.S. Citizens Only)

GRADUATE AND POSTBACCALAUREATE STUDENTS

\begin{tabular}{|c|c|c|}
\hline CHARACTERISTICS & $\begin{array}{l}\text { Nlation } \\
2635)\end{array}$ & $\begin{array}{c}\text { Sample } \\
(311)\end{array}$ \\
\hline $\begin{array}{l}\frac{\text { Sex }}{M a ? e} \\
\text { Female }\end{array}$ & $\begin{array}{l}46 \% \\
54\end{array}$ & $\begin{array}{l}45 \% \\
55\end{array}$ \\
\hline $\begin{array}{l}\frac{\text { Age }^{\mathrm{a}}}{30} \text { or less } \\
31 \text { or more } \\
\text { Unknown }\end{array}$ & $\begin{array}{l}50 \% \\
49 \\
1\end{array}$ & $\begin{array}{l}52 \% \\
47 \\
7\end{array}$ \\
\hline Average: & 32.1 & 31.7 \\
\hline $\begin{array}{l}\text { Race } \\
\text { White } \\
\text { Non-White } \\
\text { Unknown }\end{array}$ & $\begin{array}{l}80 \% \\
20 \\
-\end{array}$ & $\begin{array}{l}86 \% \\
13 \\
1\end{array}$ \\
\hline $\begin{array}{l}\frac{\text { Winter Status }}{\text { In attendance fa11, winter }} \\
\text { New student } \\
\text { Returning after an absence }\end{array}$ & $\begin{array}{l}76 \% \\
5 \\
19\end{array}$ & - \\
\hline $\begin{array}{l}\frac{\text { Spring Status }}{\text { In attendance winter, spring }} \\
\text { Graduated } \\
\text { Left college (break or } \\
\text { transfer) }\end{array}$ & $\begin{array}{l}- \\
-\end{array}$ & $\begin{array}{c}74 \% \\
4 \\
22\end{array}$ \\
\hline
\end{tabular}

${ }^{a}$ Foreign students included in population age characteristics. 
(versus 7 percent of respondents), suggesting that non-respondents are at least more apathetic than respondents. ${ }^{1}$ Nonetheless, if all students had responded it seems likely that only 14 percent of the total sample did not vote in 1976. Adjusting the sample and this latter estimate for legitimate, or defensible, reasons for not voting (living outside the country, traveling overseas), only about 5 percent and 10 percent of the sample obtained and the total sample probably did not vote and differences of this magnitude should not appreciably affect results.

Originally, in the winter of 1979 , a stratified research design was proposed to eliminate possible confounding influences due to academic commitment, or enrollment-nonenrollment in graduate programs. As Table II indicates, postbaccalaureate students were 3.5 times more likely to have been "new students" and 55 percent less likely to have declared a major than graduate students in the fall of 1978. Moreover, graduate students were 14 percent more likely to be female, 15 percent more likely to be over the age of 30, and 10 percent more likley to be white than postbaccalaureate students. Consequently, it seemed possible that, as Kerlinger (1973) argues, self-selection would introduce itself in the sampling process (especially since the research design is ex post facto) and that research findings would be misleading if confounding factors were not controlled for. It also seemed plausible that, at least with

${ }^{1} A$ random sample of non-respondents was conducted after the spring survey to ascertain if they differed from respondents. Results from non-respondents, however, must be treated cautiously since only 45 percent of those sampled responded $(N=50)$. 


\begin{tabular}{|c|c|c|}
\hline \multirow[b]{2}{*}{ CHARACTERISTICS } & \multicolumn{2}{|c|}{ ACADEMIC STATUS } \\
\hline & $\begin{array}{c}\text { Graduate } \\
\text { Population } \\
(1896)\end{array}$ & $\begin{array}{c}\text { Postbaccalauregate } \\
\text { Population } \\
(2612) \\
\end{array}$ \\
\hline $\begin{array}{l}\frac{\text { Sex }}{\text { Male }} \\
\text { Female }\end{array}$ & $\begin{array}{l}42 \% \\
58\end{array}$ & $\begin{array}{l}49 \% \\
51\end{array}$ \\
\hline $\begin{array}{l}\frac{\text { Age }}{30} \text { or less } \\
31 \text { or more } \\
\text { Unknown }\end{array}$ & $\begin{array}{l}53 \% \\
46 \\
1\end{array}$ & $\begin{array}{l}55 \% \\
40 \\
5\end{array}$ \\
\hline $\begin{array}{l}\text { Race } \\
\text { White } \\
\text { Non-White }\end{array}$ & $\begin{array}{l}77 \% \\
23\end{array}$ & $\begin{array}{l}70 \% \\
30\end{array}$ \\
\hline $\begin{array}{l}\frac{\text { Major }}{\text { Business-Education }} \\
\text { Sciences-Arts } \\
\text { Unknown }\end{array}$ & $\begin{array}{l}70 \% \\
29 \\
1\end{array}$ & $\begin{array}{l}23 \% \\
22 \\
55\end{array}$ \\
\hline $\begin{array}{l}\text { Status } \\
\text { New students } \\
\text { Continuing-admit } \\
\text { No status change } \\
\text { Returning after absence }\end{array}$ & $\begin{array}{l}12 \% \\
13 \\
56 \\
18\end{array}$ & $\begin{array}{l}42 \% \\
3 \\
33 \\
22\end{array}$ \\
\hline
\end{tabular}

${ }^{2}$ Excludes those in graduate doctoral programs. ${ }^{b}$ Includes those with non-admitted graduate status. 
regard to alienation in education, research findings might differ dramatically across the two populations. Therefore, it was decided to stratify the two populations and randomly sample each. Moreover, as Stouffer (1950) suggests, it was believed that specifying a comparison group would probably decrease the likelihood "of a dozen alternative interpretations."

But even though the research design involved stratification, the sample results ( $T a b l e$ III) demonstrate few significant differences actually separate graduate from postbaccalaureate students. For instance, although there is no way to accurately determine from the sample data whether or not an individual is a "new student," information is available on average quarters enrolled and enrollment during winter-spring. While graduate students were found to be significantly more likely to have been enrolled in the winter and spring of 1979 than were postbaccalaureate students, there were no significant differences with regard to average number of credits currently enrolled in and average number of quarters in attendance at PSU. Furthermore, although there were significant differences in the choice of majors between the two groups, postbaccalaureate students were not overwhelmingly more likely to list their major as undeclared, as the fall students were.

Of course, if the two groups were actually similar, as the socio-demographic data suggests, one would expect to find little or no significant differences between graduate and postbaccalaureate students on the alienation items. Table IV confirms this expectation: only 1 out of 12 items reflected a significant difference. 
TABLE III

SAMPLE CHARACTERISTICS OF GRADUATE AND POSTBACCALAUREATE STUDENTS, SPRING 1979

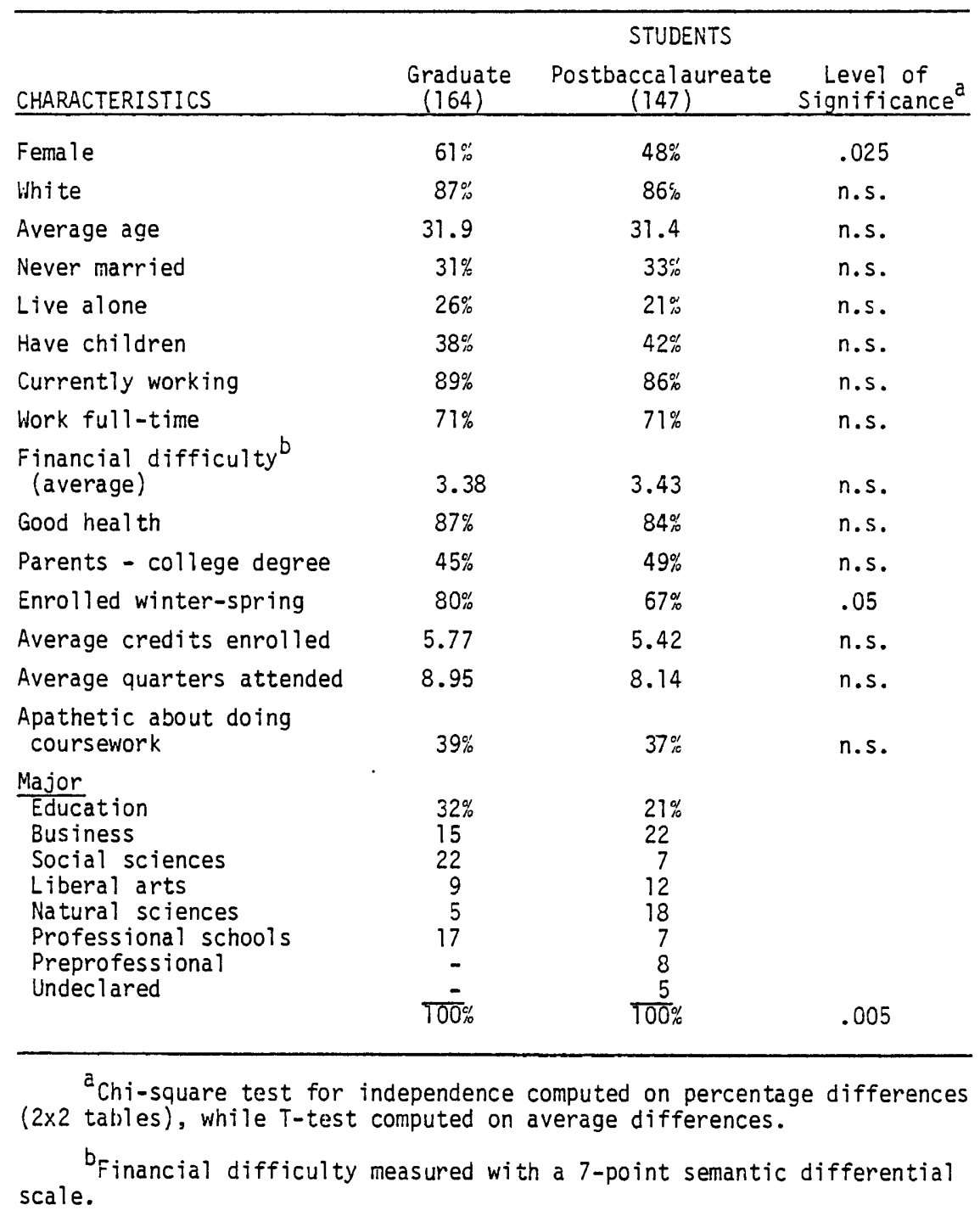


TABLE IV

RESPONSES OF GRADUATE AND POSTBACCALAUREATE STUDENTS

ON MEASURES OF ALIENATION

(Average Responses)

\begin{tabular}{|c|c|c|c|}
\hline \multirow[b]{2}{*}{ MEASURES OF ALIENATION } & \multicolumn{3}{|c|}{ STUDENTS } \\
\hline & $\begin{array}{l}\text { Graduate } \\
(150)\end{array}$ & $\begin{array}{c}\text { Post- } \\
\text { baccalaureate } \\
\text { (137) }\end{array}$ & $\begin{array}{l}\text { Level of } \\
\text { Significanceb }\end{array}$ \\
\hline Voting for leaders useless & 2.15 & 2.11 & n.s. \\
\hline $\begin{array}{l}\text { Government democratic in name } \\
\text { only }\end{array}$ & 2.68 & 2.54 & n.s. \\
\hline Two-party system viable & 3.53 & 3.45 & n.s. \\
\hline Being politically aware matters & 2.12 & 2.10 & n.s. \\
\hline Need to restrict power of elites & $5 \quad 3.11$ & 2.91 & n.s. \\
\hline $\begin{array}{l}\text { Citizens can influence govern- } \\
\text { ment }\end{array}$ & 2.70 & 2.71 & n.s. \\
\hline $\begin{array}{l}\text { Students can influence things } \\
\text { at PSU }\end{array}$ & 3.01 & 2.65 & .005 \\
\hline PSU offers relevant education & 2.63 & 2.66 & n.s. \\
\hline $\begin{array}{l}\text { Getting education - job } \\
\text { certification }\end{array}$ & 2.11 & 2.07 & n.s. \\
\hline $\begin{array}{l}\text { Students can't change class } \\
\text { requirements }\end{array}$ & 2.74 & 2.68 & n.s. \\
\hline $\begin{array}{l}\text { Protesting professor's unfair- } \\
\text { ness harmful }\end{array}$ & 2.66 & 2.51 & n.s. \\
\hline $\begin{array}{l}\text { So much knowledge, writing } \\
\text { useless }\end{array}$ & 2.24 & 2.14 & n.s. \\
\hline
\end{tabular}

${ }^{a}$ Missing data causes the number of respondents to fluctuate from measure to measure, but not appreciably. Mean respondents reported across all measures.

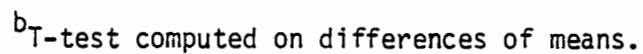


Consequently, there now appears little reason to stratify the results and in future tabulations the two groups will be regarded as one. Finally, there are a number of possible explanations for the differences between the fall 1978 postbaccalaureate population and the spring 1979 postbaccalaureate sample. First, since the spring sample closely resembles the spring population, the notion that the sample is grossly unrepresentative can be dismissed rather safely. Second, either the spring population has itself changed since the fall or perhaps the spring and fall populations are comprised of different students altogether. Unfortunately, neither interpretation can be empirically verified, since the Office of Institutional Research has not studied attrition among postbaccalaureate students. Third, with regard to major, the 91 percent decrease in the proportion with undeclared majors may be superficial: that is, postbaccalaureate students probably listed on the questionnaire the major program they have done the most work in, rather than their official major, which may well be undeclared. This seems to indicate the gross categorization of students by declared-undeclared major was originally misleading and may not serve to demonstrate commitment at all, especially since postbaccalaureate students were found to be no more apathetic about doing coursework than graduate students (Table III). Therefore, stratification seems inappropriate.

\section{OPERATIONALIZATION OF ALIENATION}

Schacht (1970) criticizes sociologists for regarding alienation primarily as an operational rather than conceptual problem. He 
argues types of alienation are more often than not conceived operationally. Schacht elaborates:

- . sociologists as a rule formulate their conceptions of alienation in terms of the occurrence of certain feelings and attitudes. . . What is signifiant is the fact that, because of the importance attached to the operationalization of the conceptions of alienation involved, and because of the way in which they are operationalized, these conceptions in effect come to be construed in terms of the test items employed (Schacht, 1970:192-193).

Thus, Schacht concludes it is doubtful whether measures so developed possess "any broad applicability."

Ironcially, Schacht may be correct, but his argument weak. That is, it may well be that the process of operationalization, because validating particular measures is exacting, commandeers too much of the sociologist's time and resources so that ignoring general conceptualizations of alienation seems excusable: the point Schacht seems to intend. Yet the major fault with this process might be, as Fischer (1976) points out, that sociological operationalizations of alienation are often too broadly focused to have any real applicability, any real chance of differentiating the alienated from the non-alienated.

In any case, after reviewing the literature on alienation scales, it was decided to avoid utilizing previous scales for two essential reasons: 1ack of context-specificity and possible lack of validity. That is, many of the scales, such as those devised by Srole (1956) and Nettler (1957), seem to capture an amorphous quality of discontent rather than alienation. For instance, Nettler contends that an agree response to these items indicates alienation: 
Do you agree or disagree?

1) Our public education is in pretty sorry shape.

2) Life, as most men live it, is meaningless.

3) Most people live lives of quiet desperation.

4) If people really admitted the truth, they would agree that children are more often a nuisance than a pleasure to their parents (Nettler, 1957:670-677).

Moreover, as Robinson and Shaver (1973) point out, few of the more familiar alienation scales have had validity tests performed on them. Thus, it seemed better to rely on conceptual definitions of alienation, as Schacht (1970) suggests, and to devise a new scale, then to venture using one or more scales which appear not only inadequate, but outmoded.

To this end, conceptual definitions of alienation, or more specifically, powerlessness and meaninglessness, from Seeman (1959) and Hajda and Travis (1978) were utilized. Powerlessness is defined by them in two ways: 1) the feeling that one cannot control events as one would like to (Seeman, 1959); and 2) the "judgment of wrongness about having no choice" (Hajda and Travis, 1978:9).

For the most part, definitions of powerlessness and meaninglessness from Hajda and Travis were applied in constructing a political alienation scale, while definitions from Seeman were utilized in fashioning an alienation in education scale. This was done, as previously stated, to avoid the use of inadequate or outmoded scales. Sometimes, however, the general idea of an item was stimulated by studying previous scales, with the notion that 
simplicity in presentation should characterize the modified item, like Question 2 (Q2)--which was fashioned from a lengthier statement Yankelovich (1972) used in his national survey on student alienation.

More specifically, the political meaninglessness items, Q1, Q3, Q4, are derived from the notion that people who feel it is meaningless to engage in politics no doubt believe the political system confronts them with a set of meaningless choices. Therefore, voting in national elections, identifying with political parties, or even remaining politically aware may be deemed a useless preoccupation. Additionally, the political powerlessness items, Q2, Q5, Q6, were also derived from Hajda and Travis. This was done because people who feel powerless may believe they have also been wronged-especially Americans. More importantly, the real value in applying the general work of Hajda and Travis in constructing the particular items lies in their presupposition that an individual feels politically alienated not merely because he is confused or frustrated (as Seeman assumes) but because he is intelligent and aware-something one would expect of graduate students.

Regarding alienation in education, however, it was assumed that the alienated would more likely be confused or frustrated by their involvement in education. This assumption was based on a general knowledge of the institution and on specific acquaintances with several dissatisfied graduate students. Simply put, in an environment where most graduate students appear committed to educating themselves, at the price of personal sacrifice, an 
alienated individual would seem out of place and therefore a stranger. Blame would more than not fall on the individual rather than on the institution. As such, Seeman's social psychological definition of powerlessness was used exclusively to construct the powerlessness in education scale, Q14, Q17, Q18. Nonetheless, since many graduate students are old enough to have participated in campus demonstrations as undergraduates during the Vietnam era, it was necessary to utilize systemic conceptions of alienation for the meaninglessness in education scale. Specifically, Q15 and Q16 are based on the work of Hajda and Travis, while Q19 reflects Seeman's social psychologism.

To be sure, the questionnaire was pretested twice: first, in the fall of 1978 in two upper-division sociology classes comprised only of sociology majors; and second, in the winter of 1979 among a random sample of graduate students. Although the response rate, 72 percent $(\mathrm{N}=32)$, was adequate for the fall pretest, the fact only 26 percent $(N=23)$ were graduate students argued against the the representativeness of the first pretest. Consequently, after revising the questionnaire from results of the first pretest, another was conducted. Unlike the first, which was self-administered in a controlled environment, the second pretest was conducted through the mail, giving some indication of possible success or failure before the spring survey. A response rate of 70 percent was obtained--rather remarkable given the fact the questionnaire was mailed out the week before finals. Item-analysis and internal consistency tests were performed on the alienation scale and 
revisions made accordingly. The final scale, as administered in the spring survey, was operationalized as follows:

Q1 - Voting for national leaders is rather useless.

Q2 - The U.S. Government is democratic in name only.

Q3 - The present two-party system generally offers real alternatives.

Q4 - Being aware of national political issues really does matter.

Q5 - Until we restrict the political power of elites, we will never solve our national problems.

Q6 - The average citizen still can influence what the U.S. Government proposes to do.

Q14 - Administrators and faculty may have more institutional power, but students generally can influence things to their own benefit.

Q15 - This university provides students with an education relevant to their needs.

Q16 - Getting an education means little more than being certified to do a job.

Q17 - When it comes to changing class requirements, students can't do much more than complain among themselves.

Q18 - If a professor treats you unfairly, making an official protest will probably do you more harm than good.

Q19 - So much knowledge exists today that what I write for classes is rather useless in comparison.

Responses to each measure were ordered along a slightly modified Likert Scale, with respondents asked to report whether they "strongly disagree," "disagree," were "divided," "agree," or "strongly agree" with each statement. The scale was modified to include a "divided" mid-point, rather than the conventional "neither" or "neutral," for both theoretical and empirical reasons. 
As Hajda and Travis (1978) imply, the sociology of alienation has tended to ignore ambivalence, even though ambivalence is probably more prevalent than alienation. Including an ambivalent mid-point reduces the black and white nature of "agree-disagree" scales, especially for those who are only somewhat alienated and might otherwise be forced to choose between an alienated response or no response at all, thereby diminishing the integrity of the study. Furthermore, it was decided to include a residual, or "don't know," response in the measures, so to differentiate between those ambivalent about the issue and those either who did not understand the measure or who did not believe they possessed enough information to venture a response (see Oppenheim, 1966 for a thorough discussion). To make this distinction sharper and to clarify the interpretation of the mid-point, a "divided" response seemed most appropriate. Finally, measures were alternately framed in positive and negative directions, avoiding the major fault many alienation scales suffer from--"the lack of control over agreement response set" (Robinson and Shaver: 1973:245). Not only does this fault contribute to an overestimation of those alienated, but Robinson and Shaver contend that internal consistency and unidimensionality may be spuriously affected by an agreement response set.

\section{RELIABILITY AND VALIDITY OF THE ALIENATION SCALE}

Reliability and validity of the measures of powerlessness and meaninglessness were assessed by several techniques: item-analysis, internal consistency, and criterion-related validity. Multiple 
assessment was deemed necessary, rather than relying solely on the convention of internal consistency, because of recent criticism of how loosely-fashioned alienation measures often are (Robinson and Shaver, 1973; Fischer, 1976).

With regard to item-analysis, all measures significantly differentiated between the lowest and highest quartiles on each Likert Scale (Table V). For instance, an absolute difference of 2.28 separates the 25 percent of the respondents on the low side from the 25 percent on the high side of the scale on Question 6, while the variance for both groups is low, or in other words, reflects homogeneous responses within each group. Both of these facts, large differences of means and low variances, contribute to the rather large t-test statistics. Consequently, these results indicate that: 1) measures were worded well enough to avoid the problem of a response set; 2) measures appear to differentiate the alienated from the non-alienated; and 3) an adequate number of alienated responses should be available for subsequent analysis.

With internal consistency, however, the evidence is not entirely clear. Cronbach's alpha on measures of powerlessness and meaninglessness was found to be .63 and .62 respectively. Though this is adequate, it is far from preferred, and several possible reasons may account for these moderate reliability coefficients: 1) some liberals and radicals took issue with the particular wording or direction of alienation measures, indicating they may have regarded some items as ambiguous, too broad, or slanted and thus "lost faith" in the survey; 2) the lack of control over 
TABLE V

ITEM-ANALYSIS OF MEASURES OF ALIEIATTION, SPRING SURVEY: 1979

\begin{tabular}{|c|c|c|c|c|c|c|c|c|}
\hline \multirow[b]{2}{*}{$\begin{array}{l}\text { MEASURES OF } \\
\text { ALIENATION }\end{array}$} & \multirow[b]{2}{*}{$\begin{array}{l}\text { Low } \\
\text { Mean }\end{array}$} & \multicolumn{7}{|c|}{ ITEM CHARACTERISTICS } \\
\hline & & $\begin{array}{l}\text { High } \\
\text { Hean } \\
\end{array}$ & $\begin{array}{c}\text { Low } \\
\text { Variance } \\
\end{array}$ & $\begin{array}{c}\text { High } \\
\text { Variance } \\
\end{array}$ & $\begin{array}{l}\text { Number } \\
\text { of Cases } \\
\end{array}$ & $\begin{array}{c}T \text {-Test } \\
\text { Statistic } \\
\end{array}$ & $\begin{array}{c}\text { Degrees of } \\
\text { Freedom }\end{array}$ & $\begin{array}{c}\text { Level of } \\
\text { Significance }\end{array}$ \\
\hline $\begin{array}{ll}\text { Question } & 1 \\
\text { Question } & 2 \\
\text { Question } & 3 \\
\text { Question } & 4 \\
\text { Question } & 5 \\
\text { Question } & 6 \\
\text { Question } 14 \\
\text { Question } 15 \\
\text { Question } 16 \\
\text { Question } 17 \\
\text { Question } 18 \\
\text { Question } 19\end{array}$ & $\begin{array}{l}1.00 \\
1.57 \\
2.16 \\
1.00 \\
1.70 \\
1.84 \\
1.80 \\
1.75 \\
1.00 \\
1.66 \\
1.62 \\
1.12\end{array}$ & $\begin{array}{l}3.53 \\
4.09 \\
4.67 \\
3.70 \\
4.35 \\
4.12 \\
4.15 \\
3.72 \\
3.79 \\
4.18 \\
3.95 \\
3.64\end{array}$ & $\begin{array}{c}. \\
.248 \\
.161 \\
- \\
.215 \\
.135 \\
.166 \\
.190 \\
- \\
.227 \\
.240 \\
.108\end{array}$ & $\begin{array}{l}.493 \\
.268 \\
.224 \\
.854 \\
.230 \\
.399 \\
.130 \\
.344 \\
.435 \\
.147 \\
.272 \\
.509\end{array}$ & $\begin{array}{l}152 \\
152 \\
152 \\
152 \\
138 \\
152 \\
146 \\
144 \\
152 \\
136 \\
126 \\
148\end{array}$ & $\begin{array}{l}31.38 \\
30.78 \\
35.31 \\
25.45 \\
33.02 \\
27.16 \\
37.05 \\
22.89 \\
36.87 \\
33.88 \\
25.90 \\
27.52\end{array}$ & $\begin{array}{r}75 \\
151 \\
146 \\
69 \\
135 \\
120 \\
141 \\
131 \\
75 \\
128 \\
123 \\
102\end{array}$ & $\begin{array}{l}.0001 \\
.0001 \\
.0001 \\
.0001 \\
.0001 \\
.0001 \\
.0001 \\
.0001 \\
.0001 \\
.0001 \\
.0001 \\
.0001\end{array}$ \\
\hline
\end{tabular}

$a_{T-\text { test formula: }}$

$$
t=\frac{\bar{x}_{1}-\bar{x}_{2}}{\sqrt{\sigma_{x_{1}}^{2} / N_{1}+\sigma_{x_{2}}^{2} / N_{2}}} \text { This formula assumes unequal variance. }
$$


self-administration may have resulted in a variety of confounding influences--such as interruptions or input from others--affecting responses; and 3) the alienation scale is rather new, and further expansion of the scale may improve internal consistency. Nonetheless, reliability is a necessary but not a sufficient condition for high validity. As one researcher argues, "A test can have high reliability and not be valid for any particular purpose" (Nunnally, $1959: 95)$.

For this reason, it was decided to assess how accurately the alienation items measure what they purport to. As such, it was predicted that the politically powerless would be more apt to regard the U.S. political system as unjust than those who are ambivalent or not alienated, that those who judge political affairs as meaningless would be more apt to be apolitical or apathetic, that those who experience powerlessness in education would be more apt to regard faculty control of departments as unfair, and that those who experience meaninglessness in education would be more apt to feel apathetic toward coursework.

With the exception of Q17, all predictions were upheld. In Table VI, for instance, all political powerlessness predictions are highly significant: on the average the Mann-Whitney mean ranks of the alienated are 39 percent greater than for the not alienated. This indicates the alienated tended to respond more on the "very unjust" side of the semantic differential.

In contrast, two criteria were needed to validate the political meaninglessness scale (Table VII). Although both Q1 and Q3 display 
TABLE VI

CRITERION-RELATED VALIDITY TEST OF POLITICAL POWERLESSNESS SCALE

\begin{tabular}{|c|c|c|c|c|c|}
\hline & \multicolumn{5}{|c|}{ STATISTICAL CHARACTERISTICS } \\
\hline & $\begin{array}{l}\text { Mean } \\
\text { Rank }\end{array}$ & $\begin{array}{l}\text { Number of } \\
\text { Respondents }\end{array}$ & $\begin{array}{c}\text { Mann-Whitney } \\
\text { Statistic }\end{array}$ & $\begin{array}{c}Z \\
\text { Statistic }\end{array}$ & $\begin{array}{c}\text { Level of } \\
\text { Significance } \\
\end{array}$ \\
\hline$\frac{\text { CONSIDER U.S. }}{\text { MENT UNJUST }}$ & & & & & \\
\hline $\begin{array}{l}\frac{\text { Question } \# 2}{\text { Not alienated }} \\
\text { Al ienated }\end{array}$ & $\begin{array}{l}134.9 \\
196.4\end{array}$ & $\begin{array}{r}(229) \\
(68)\end{array}$ & 4563 & -5.35 & .0001 \\
\hline $\begin{array}{l}\text { Question } \frac{\pi}{\pi} \\
\text { Not Alienated } \\
\text { Alienated }\end{array}$ & $\begin{array}{l}130.4 \\
176.6\end{array}$ & $\begin{array}{r}(193) \\
(98)\end{array}$ & 6454 & -4.57 & .0001 \\
\hline $\begin{array}{l}\frac{\text { Question \#6 }}{\text { Not Alienated }} \\
\text { Al ienated }\end{array}$ & $\begin{array}{l}138.7 \\
188.8\end{array}$ & $\begin{array}{r}(236) \\
(67)\end{array}$ & 4772 & -4.19 & .0001 \\
\hline
\end{tabular}

aThe question read: "As a system, how just or unjust do you think the U.S. Government is?" Responses were ordered along a 7-point semantic differential scale. A response of "very unjust" has a value of 7 , while a response of "very just" has a value of 7 . 
TABLE VII

CRITERION-RELATED VALIDITY TEST OF POLITICAL MEANINGLESSNESS SCALE

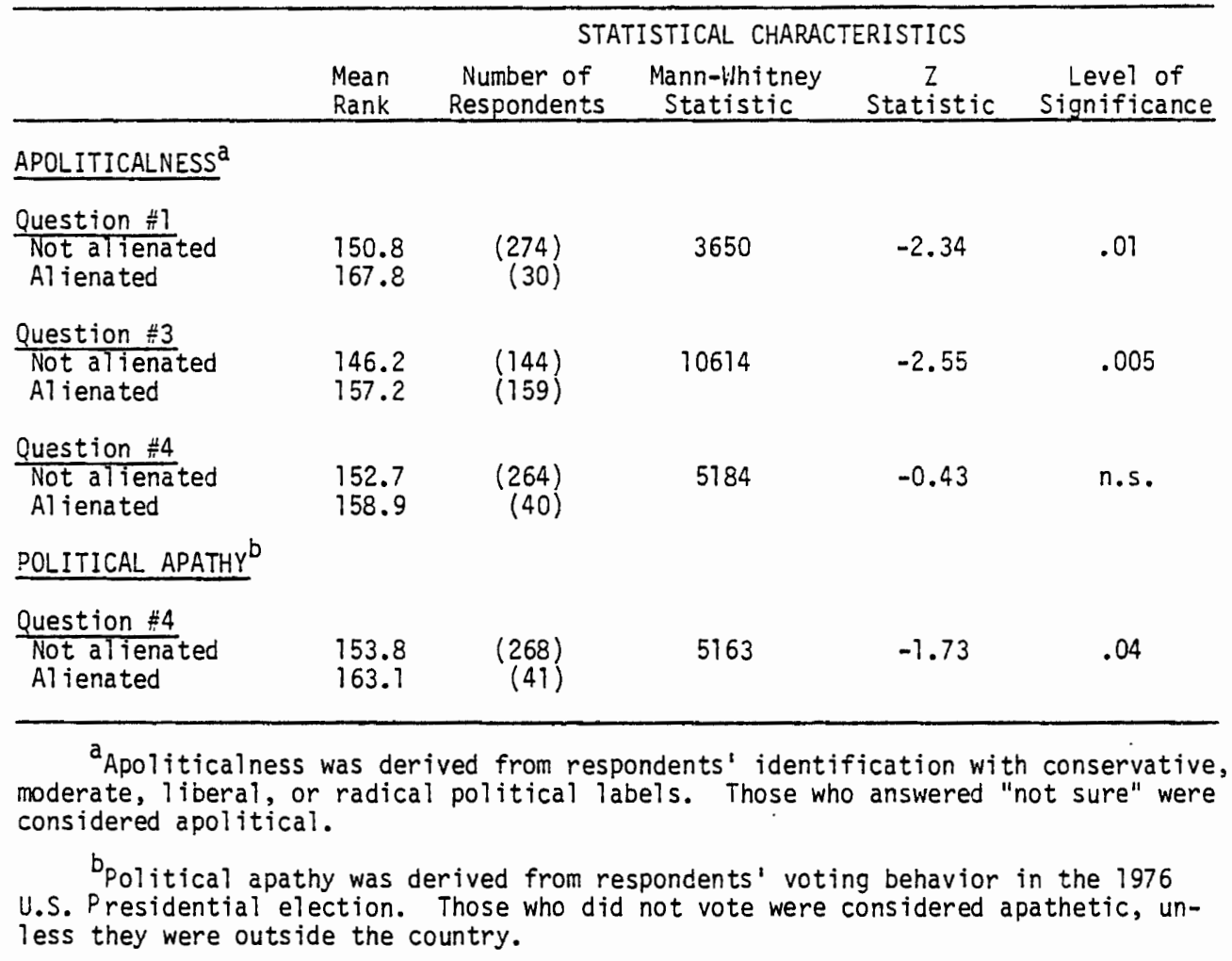


significant results, with an average mean rank differential of 9 percent, Q4 failed to differentiate between the alienated and not alienated on apoliticalness. Regarding political apathy, however, Q4 significantly differentiated between the two, upholding one of the original predictions--that, if the measures are valid, those who checked alienation responses should be more likely to be apolitical or politically apathetic than those who checked not alienated responses.

Results from the Mann-Whitney tests on the meaninglessness in education scale, moreover, indicate that again predictions were upheld for all items (Table VIII). The mean ranks of the alienated are generally 40 percent greater than for the not alienated, indicating the alienated tended to feel more apathetic about doing coursework than did the not alienated--something one would expect if the indicators are measuring meaninglessness.

Finally, the tests on the powerlessness in education scale show mixed results (Table IX), Although the original prediction was upheld for Q14, neither Q17 nor Q18 directly passed the validity test. This may reflect lack of validity, but is more likely a product of the 65 percent non-response rate on the combination of the criterion and the alienation measures: many respondents simply answered "don't know" on the question of faculty control being fair. Furthermore, the non-response rates ("don't knows" and "no answers") on Q17 and Q18 averaged 14.9 percent, compared to an average of 3.8 percent on the balance of alienation measures (on 5 out of 6 of the political alienation measures the average non-response rate was 
TABIE VIII

CRITERION-RELATED VALIDITY TEST OF MEANINGLESSNESS IN EDUCATION SCALE

\begin{tabular}{|c|c|c|c|c|c|}
\hline & $\begin{array}{l}\text { Mean } \\
\text { Rank }\end{array}$ & $\begin{array}{l}\text { Number of } \\
\text { Respondents }\end{array}$ & $\begin{array}{l}\text { Mann-Whitney } \\
\text { Statistic }\end{array}$ & $\stackrel{2}{\text { Statistic }}^{2}$ & $\begin{array}{c}\text { Level of } \\
\text { Significance }\end{array}$ \\
\hline$\frac{\text { APATHETIC ABOUT }}{\text { COURSEWORK }}$ & & & & & \\
\hline $\begin{array}{l}\frac{\text { Question } \# 15}{\text { Not alienated }} \\
\text { Alienated }\end{array}$ & $\begin{array}{l}143.4 \\
197.5\end{array}$ & $\begin{array}{r}(257) \\
(45)\end{array}$ & 3714 & -3.87 & .0001 \\
\hline $\begin{array}{l}\frac{\text { Question } \frac{16}{1}}{\text { Not al ienated }} \\
\text { Al ienated }\end{array}$ & $\begin{array}{l}141.2 \\
206.6\end{array}$ & $\begin{array}{r}(253) \\
(50)\end{array}$ & 3596 & -4.88 & .0001 \\
\hline $\begin{array}{l}\frac{\text { Question } \frac{\| 19}{t N}}{\text { Not alienated }} \\
\text { Al ienated }\end{array}$ & $\begin{array}{l}144.3 \\
194.4\end{array}$ & $\begin{array}{r}(263) \\
(37)\end{array}$ & 3240 & -3.33 & .0005 \\
\hline
\end{tabular}

aThe question read: "How often do you feel apathetic about doing coursework?" Responses were ordered along a 7-point semantic differential scale. A response of "very often" has a value of 7 , while a response of "hardly ever" has a value of 1 . 
TABLE IX

CRITERION-RELATED VALIDITY TEST OF POWERLESSNESS IN EDUCATION SCALE

\begin{tabular}{|c|c|c|c|c|c|}
\hline & $\begin{array}{l}\text { Mean } \\
\text { Rank }\end{array}$ & $\begin{array}{c}\text { Number of } \\
\text { Respondents }\end{array}$ & $\begin{array}{l}\text { Mann-Whitney } \\
\text { Statistic }\end{array}$ & $\begin{array}{c}Z \\
\text { Statistic } \\
\end{array}$ & $\begin{array}{c}\text { Level of } \\
\text { Significance } \\
\end{array}$ \\
\hline \multicolumn{6}{|c|}{ CONSIDER FACULTY CONTROL UNFAIR } \\
\hline $\begin{array}{l}\frac{\text { Question \#14 }}{\text { Not alienated }} \\
\text { Alienated }\end{array}$ & $\begin{array}{l}54.1 \\
68.7\end{array}$ & $\begin{array}{l}(87) \\
(27)\end{array}$ & 881 & -2.01 & .02 \\
\hline $\begin{array}{l}\text { Question } \# 17 \\
\text { Not alienated } \\
\text { Alienated }\end{array}$ & $\begin{array}{l}42.8 \\
41.8\end{array}$ & $\begin{array}{l}(57) \\
(27)\end{array}$ & 750 & -0.19 & n.s. \\
\hline $\begin{array}{l}\text { Question } \frac{1}{\pi} 18 \\
\text { Not alienated } \\
\text { Alienated }\end{array}$ & $\begin{array}{l}41.5 \\
46.6\end{array}$ & $\begin{array}{l}(68) \\
(16)\end{array}$ & 478 & -0.77 & n.s. \\
\hline ALIENATED IN EDUCATION ${ }^{c}$ & & & & & \\
\hline $\begin{array}{l}\text { Question } \# 17 \\
\text { Consider authority fair } \\
\text { Consider authority unfair }\end{array}$ & $\begin{array}{l}42.7 \\
50.5\end{array}$ & $\begin{array}{l}(68) \\
(20)\end{array}$ & 559 & -1.25 & n.s. \\
\hline $\begin{array}{l}\text { Question } \frac{\pi}{\pi} 18 \\
\text { Consider authority fair } \\
\text { Consider authority unfair }\end{array}$ & $\begin{array}{l}41.8 \\
53.7\end{array}$ & $\begin{array}{l}(68) \\
(20)\end{array}$ & 496 & -1.94 & .025 \\
\hline
\end{tabular}

a Since most "don't know" responses on Q17 and Q18 were from respondents not currently enrolled, enrollment was controlled for on these $i$ tems to eliminate possible bias bue to the self-selectivity of those not currently enrolled, spring 1979, but who responded nontheless. Moreover, because less than 4\% responded "don ' $t$ know" on Q14 (versus 10\% for Q17 and $17 \%$ for Q18), no adjustment was necessary for Q14.

bThe question read: "Do you consider PSU's departmental system a fair or unfair way to govern things?" It was introduced with particular reference to faculty control of most departments. Responses were ordered along a 7-point semantic differential scale. A response of "very unfair" has a value of 7 , while a response of "very fair" has a value of 1 .

${ }^{C}$ Since the predictions for $Q 17$ and $Q 18$ were not upheld, a weaker test was applied, since missing data occurred on both alienation items and the criterion for about $65 \%$ of the respondents. As such, the mean ranks reflect alienation scores: a response of "very alienated" has a value of 5 , while a response of "not al jenated" has a value of 1 . 
only 1.6 percent). So because the criterion was riddled with nonresponse, it seemed unwise to eliminate both Q17 and Q18 merely on the results of the original validity test.

Thus, to assess the predictive discriminatory power of Q17 and Q18 a weaker test was applied. It was predicted those who consider department control unfair should experience powerlessness and those who do not consider such control unfair should not experience powerlessness. The inductive logic of this test is as follows: if the criterion (in this case the alienation item) measures alienation, then the semantic differential measures fairness-unfairness; consequently, if the prediction is upheld, then the semantic differential probably measures fairness-unfairness, which indirectly suggests the criterion probably measures alienation. ${ }^{1}$ Yet as the results in Table IX indicate, Q17 appears invalid, while Q18 may well be a valid measure of alienation. Thus, Q17 was dropped from the scale so the analysis of the hypotheses (Chapter IV) would not be distorted by invalidity, while Q18 was retained.

\section{OPERATIONALIZATION OF PERCEPTIONS OF COMMUNITY, POWER, AND AUTHORITY}

Since community relations in the individual's life are vast, it was necessary to use more than one indicator of community. To that end, students were asked: "Do you generally feel a sense of

${ }^{1}$ Normally, as in deductive logic, reasoning from the consequent to the antecedent would involve the logical fallacy of affirming the consequent. However, as Baker (1974) points out, such formal restrictions are not entirely applicable to inductive logic, since one claims only that the premise helps to make the conclusion reasonable to believe. 
community, or togetherness, concerning . . your family? PSU?

Oregon? [and] America?" By asking for one's general feeling, rather than one's current feeling, it was hoped ephemeral feelings, whether positive or negative, could be avoided.

Moreover, rather than subject respondents to a profusion of jargon, such as functional relevance or social integration (terms Nisbet utilizes to characterize community), respondents were merely asked if they felt that togetherness characterized their relations. This shifted the indicator's emphasis to whether or not relations were mutually supportive and meaningful. As such, the indicator assumes that if relations are meaningful, they are also integrative and relevant.

Regarding perceptions of power and authority relations, two indicators were used: 1) "As a system, how just or unjust do you think the U.S. Government is?" and 2) "Do you consider PSU's departmental system a fair or unfair way to govern things?" Although the political and educational realms were focused on for a priori reasons in the study design (politics was deemed to reflect a priori power relations, while education a priori authority relations), it was decided respondent's own perceptions of such relations should be utilized in the analysis, since this would avoid the logical fallacy of begging the question, or accepting an argument on mere faith.

Both perceptual items were ordered along 7-point semantic differential scales. Those who responded "unjust" or "unfair" seem to indicate perceptions of power relations (PPR) between the institution 
and the individual, while those who responded "just" or "fair" seem to indicate perceptions of authority relations (PAR) between the institution and the individual. More specifically, any response 5 or above on the scale (either on the "unjust" or "unfair" poles) indicates PPR. Of course, those responding at the midpoint or below indicates PAR. This assignment of midpoint responses to the latter group rules out the possibility that indefinite perceptions will be mixed up with $P P R$ and makes subsequent analysis clearer. 
CHAPTER IV

\section{RESULTS}

\section{POWERLESSNESS AND MEANINGLESSNESS}

As Table $\mathrm{X}$ indicates, the null hypothesis that powerlessness and meaninglessness are positively related receives preliminary rejection. Rank order correlations were computed on only those who experienced at least powerlessness or meaninglessness. ${ }^{1}$ Subsequently, respondents who felt purely ambivalent, or purely not alienated were eliminated from consideration: after all, the issue is whether powerlessness and meaninglessness are positively related, not whether particular statements are positively related. This done, the mean negative zero-order correlation is -.444, with 79 percent of the correlations highly significant. Only one measure of meaninglessness, Q3, shows consistently low correlations across al1 powerlessness measures.

It is possible though that these consistently low correlations, as well as others, may be differentially affected or even distorted

${ }^{1}$ Since 75 percent of the distributions of alienation measures exhibited Chi-square, or approximately Chi-square, distributions, ordinal-level measures of association, specifically Spearman's Rho and Kendall's Tau , were utilized. Recent interest in and experiments with ordinal analysis (Hawkes, 1971; Quade, 1974; and Reynolds, 1974) also serve to reaffirm or expand upon the non-parametric statistical model standardized by Siegel (1956). For instance, a classic experimental work demonstrates that when distributions are non-linear, the chances of finding spurious correlations are greater with Kendall's Rank-Order Coefficient, Tau (Reynolds, 1974). 
TABLE $X$

ZERO-ORDER RANK CORRELATIONS BETWEEN

POWERLESSNESS AND MEANINGNESSNESS

\begin{tabular}{|c|c|c|c|c|c|}
\hline \multirow[b]{2}{*}{ MEANINGLESSNESS } & \multicolumn{4}{|c|}{ POWERLESSNESS. } & \multirow[b]{2}{*}{ Q18 } \\
\hline & Q2 & Q5 & Q6 & Q14 & \\
\hline Q1 & $\begin{array}{r}149 * \\
(83)\end{array}$ & $\begin{array}{r}.141 * \\
(110)\end{array}$ & $\begin{array}{c}-.449 \star \star \star \star \\
(82)\end{array}$ & $\begin{array}{c}-.329 * \star \star \star \\
(94)\end{array}$ & 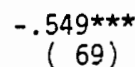 \\
\hline Q3 & $\begin{array}{l}.012 \\
(175)\end{array}$ & $\begin{array}{c}-189 * * \\
(177)\end{array}$ & $\begin{array}{r}-.084 \\
(175)\end{array}$ & $\begin{array}{r}-126^{*} \\
(183)\end{array}$ & $\begin{array}{r}-.207 * \star \\
(145)\end{array}$ \\
\hline Q4 & $-\left(\begin{array}{c}623^{* * *} \\
(97)\end{array}\right.$ & $\begin{array}{c}-.602^{\star \star \star} \\
(124)\end{array}$ & $\begin{array}{c}-.628 * \star \star \\
(91)\end{array}$ & $\begin{array}{c}-.547 \star \star \star \\
(104)\end{array}$ & $\begin{array}{c}-.665^{* \star *} \\
(82)\end{array}$ \\
\hline Q15 & $\begin{array}{c}-539 \star * \star \\
(100)\end{array}$ & $\begin{array}{c}-337^{\star \star \star \star} \\
(112)\end{array}$ & $\begin{array}{c}-.469 * \pi * \\
(87)\end{array}$ & $\begin{array}{c}-.441^{\star \star *} \\
(100)\end{array}$ & $\begin{array}{c}-.648^{* \star \star *} \\
(82)\end{array}$ \\
\hline Q16 & $\begin{array}{c}-467 \star \star \star \star \\
(101)\end{array}$ & $\begin{array}{c}-413^{* \star \star *} \\
(128)\end{array}$ & $\begin{array}{c}-.575 * \star \star \star \\
(100)\end{array}$ & $\begin{array}{c}-.544 * \pi * \\
(109)\end{array}$ & $\begin{array}{c}-.539 * \pi \star \\
(82)\end{array}$ \\
\hline Q19 & $-i^{-616^{\star \star \star}}$ & $\begin{array}{c}-444^{\star \star \star *} \\
(119)\end{array}$ & $\begin{array}{c}-.532 \pi \pi \star \\
(86)\end{array}$ & $\begin{array}{c}-.509 * \pi \star \\
(100)\end{array}$ & $\begin{array}{c}-.528 * \star \star \\
(65)\end{array}$ \\
\hline
\end{tabular}

*Significant, $\rho=.05$.

$\star *$ Significant, $\rho=.01$.

$\star \star \star$ Significant, $p=.001$.

${ }^{a}$ Spearman Rank Correlation Coefficients. 
by respondent's sex. Table XI illustrates this fact quite clearly, especially regarding Q3. In this instance correlations on women are sufficiently low to be generally considered non-correlations, while correlations on men are sufficiently high to be generally regarded as modest negative correlations. Concerning the viability of political parties, the power of elites, and one's influence on the government, over a third of women experience both powerlessness and meaninglessness. Women are almost one and a half times more likely to experience total alienation (that is, the experience of both powerlessness and meaninglessness) than men. This should come as no surprise given the recent rise of the "New Feminism," which is, as one intellectual proclaims, a "radical insight" meant to replace an "unjust and dangerous" patriarchy that "has left us no choice but to dissolve it.. . it is time for women to weld the instrumentalities of power" (Pollock, 1972:19).

Moreover, it may well be that women; especially the collegeeducated, are increasingly skeptical about expecting any meaningful social change can result from conventional politics. After all it is politics as usual which has blocked passage of the Equal Rights Amendment for so long. Pollock enunciates this sentiment:

For radical feminists... the unfinished business of the first movement is the dissolution of patriarchy--its social and political forms, and the psychological attitudes and modes of thought it generates. To gain power within existing economic or political structures, they argue, is in itself a meaningless goal, since it is the institutions of patriarchy . . . that must be replaced (Pollock, 1972:19). 
TABLE XI

ZERO-ORDER RANK CORREIATIONS BETWEEN POWERLESSNESS AND VEANINGLESSNESS AND THE PROPORTION TOTALLY ALIENATED BY SEX ${ }^{2}$

(Respondents in Parentheses)

POWERLESSNESS

MEANINGLESSNESS Question 2 Question 5 Question 6 Question 14 Question 18 Male Female Male Female Male Female Male Female Male Female

\begin{tabular}{|c|c|c|c|c|c|c|c|c|c|c|}
\hline \multicolumn{11}{|l|}{ Question 1} \\
\hline $\begin{array}{l}\text { Percent: } \\
\text { Correlation: } \\
\text { Question } 3\end{array}$ & $\begin{array}{r}18 \\
-\quad 11 \\
(34)\end{array}$ & $\begin{array}{r}22 \\
-.17 \\
. \quad(49)\end{array}$ & $\begin{array}{r}12 \\
-.24 \\
(41)\end{array}$ & $\begin{array}{r}17 \\
-.08 \\
(59)\end{array}$ & $\begin{array}{r}6 \\
(34)\end{array}$ & $\begin{array}{r}19 \\
-.34 \\
(48)\end{array}$ & $\begin{array}{r}14 \\
-.42 \\
(37)\end{array}$ & $\begin{array}{r}16 \\
-.29 \\
(57)\end{array}$ & $\begin{array}{r}7 \\
-.54 \\
(29)\end{array}$ & $\begin{array}{r}15 \\
-.54 \\
(40)\end{array}$ \\
\hline $\begin{array}{l}\text { Percent: } \\
\text { Correlation: }\end{array}$ & $\begin{array}{r}31 \\
-.04 \\
(77)\end{array}$ & $\begin{array}{r}34 \\
.04 \\
(98)\end{array}$ & $\begin{array}{r}31 \\
-.40 \\
(77)\end{array}$ & $\begin{array}{r}44 \\
-.06 \\
(100)\end{array}$ & $\begin{array}{r}23 \\
-.23 \\
(77)\end{array}$ & $\begin{array}{r}34 \\
-.01 \\
(98)\end{array}$ & $\begin{array}{r}29 \\
-.22 \\
(77)\end{array}$ & $\begin{array}{c}27 \\
-.07 \\
(106)\end{array}$ & $\begin{array}{r}27 \\
-.29 \\
(60)\end{array}$ & $\begin{array}{r}25 \\
-.15 \\
(85)\end{array}$ \\
\hline Question 4 & . & & & & & & & & & \\
\hline $\begin{array}{l}\text { Percent: } \\
\text { Correlation: } \\
\text { Question } 15\end{array}$ & $\begin{array}{r}17 \\
-.54 \\
(42)\end{array}$ & $\begin{array}{r}11 \\
-.68 \\
(55)\end{array}$ & $\begin{array}{r}8 \\
-.68 \\
(50)\end{array}$ & $\begin{array}{r}12 \\
-.53 \\
(74)\end{array}$ & $\begin{array}{r}15 \\
-.61 \\
(40)\end{array}$ & $\begin{array}{r}10 \\
-.62 \\
(51)\end{array}$ & $\begin{array}{r}16 \\
-.52 \\
(44)\end{array}$ & $\begin{array}{r}3 \\
-.55 \\
(60)\end{array}$ & $\begin{array}{r}14 \\
-.61 \\
(36)\end{array}$ & $\begin{array}{r}4 \\
-.70 \\
(46)\end{array}$ \\
\hline $\begin{array}{l}\text { Percent: } \\
\text { Correlation: } \\
\text { Question } 16 \\
\end{array}$ & $\begin{array}{r}15 \\
-.54 \\
(41)\end{array}$ & $\begin{array}{r}12 \\
-.54 \\
(59)\end{array}$ & $\begin{array}{r}18 \\
-.32 \\
(44)\end{array}$ & $\begin{array}{r}21 \\
-.35 \\
(68)\end{array}$ & $\begin{array}{r}20 \\
-.45 \\
(35)\end{array}$ & $\begin{array}{r}21 \\
-.47 \\
(52\rangle\end{array}$ & $\begin{array}{r}21 \\
-.29 \\
(39)\end{array}$ & $\begin{array}{r}18 \\
-.53 \\
(61)\end{array}$ & $\begin{array}{r}12 \\
-.70 \\
(33)\end{array}$ & $\begin{array}{r}12 \\
-.63 \\
(49)\end{array}$ \\
\hline $\begin{array}{l}\text { Percent: } \\
\text { Correlation: } \\
\text { Question } 19 \\
\end{array}$ & $\begin{array}{r}19 \\
-.48 \\
(43)\end{array}$ & $\begin{array}{r}17 \\
-.45 \\
(58)\end{array}$ & $\begin{array}{r}10 \\
-.67 \\
(52)\end{array}$ & $\begin{array}{r}17 \\
-.20 \\
(76)\end{array}$ & $\begin{array}{r}18 \\
-.56 \\
(40)\end{array}$ & $\begin{array}{r}12 \\
-.57 \\
(60)\end{array}$ & $\begin{array}{r}11 \\
-.70 \\
(47)\end{array}$ & $\begin{array}{r}23 \\
-.44 \\
(62)\end{array}$ & $\begin{array}{r}20 \\
-.42 \\
(35)\end{array}$ & $\begin{array}{r}11 \\
-.61 \\
(47)\end{array}$ \\
\hline $\begin{array}{l}\text { Percent: } \\
\text { Correlation: }\end{array}$ & $\begin{array}{r}10 \\
-.64 \\
(41)\end{array}$ & $\begin{array}{r}9 \\
-.50 \\
(54)\end{array}$ & $\begin{array}{r}6 \\
-.62 \\
(48)\end{array}$ & $\begin{array}{r}14 \\
-.31 \\
(71)\end{array}$ & $\begin{array}{r}14 \\
-.58 \\
(37)\end{array}$ & $\begin{array}{r}12 \\
-.48 \\
(49)\end{array}$ & $\begin{array}{r}14 \\
-.63 \\
(42)\end{array}$ & $\begin{array}{r}12 \\
-.41 \\
(58)\end{array}$ & $\begin{array}{r}16 \\
-.57 \\
(31)\end{array}$ & $\begin{array}{r}17 \\
-.49 \\
(35)\end{array}$ \\
\hline
\end{tabular}

aproportion totally alienated refers to those experiencing both powerlessness and meaninglessness among those who experience any alienation.

bspearman Rank Correlation Coefficients. 
Nevertheless, even though female respondents exhibit more total alienation than males toward politics as usual, women, in general, are not significantly more totally alienated than men. For instance, on the average (that is, the average of the reported percentages) only 18 percent of women vs. 16 percent of men are totally alienated (Table XI).

But although this latter fact disfavors the prospects of the null, despite stratification by sex, even this fact may still be shown ultimately spurious. As such, partial rank-order correlations, Tables XII-XV, were computed to search out spurious non- and negative correlations. ${ }^{1}$ All partials are stratified by sex, since it is plausible the politicalization of some women may yet distort correlations.

However, as Table XII indicates, 5 out of 9 fifth-order partials betray the slight effects of "suppressor" variables--that is, being upset with leaders, perceiving the government as unjust,

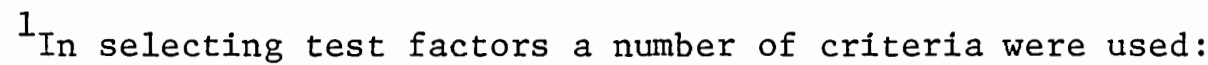
1) theoretical relevance; 2) significant positive correlations with measures of powerlessness and meaninglessness; 3) high correlations, regardless of sign, with either powerlessness or meaninglessness; and 4) a sufficiently high number of cases in common with other test factors. Subsequently a number of conventional independent variables were rejected: parental education, presence of children, voter apathy, previous political activism (Vietnam War protest), preference for living outside American society, preference for alternative explanations of the world vs. Western Rationalism, employment, health, and race. Some, if not many, of these will probably still remain fruitful factors, but in a highly educated and and rather homogeneous population such as graduate students, it is. understandable why none were important. 
IABLE XII

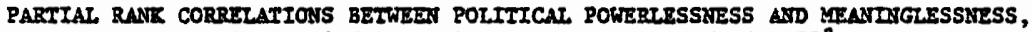
CONTROLLING FOR SELECTED IMDEPISAEMT VARIABLES

(Females Only)

$\begin{gathered}\text { PARTIAL RANK CORRELATIONS } \\ \text { (Listwise Deletion) }\end{gathered}$
$\tau_{x y} \cdot \tau_{x y \cdot 1} \tau_{x y \cdot 1,2} \tau_{x y \cdot 1,2,3} \tau_{x y \cdot 1,2,3,4} \tau_{x y \cdot 1,2,3,4,5} \begin{gathered}\text { Number of } \\ \text { Respondents }\end{gathered}$

Altenation in polities

Q3 with 02

03 with 05

Q3 with Q6

Q1 with $Q 2$

Q1 with Q5

Q1 with Q6

Q4 with Q2

Q4 with Q5

Q4 with Q6

$\begin{array}{ll}.018 & .002 \\ -.065 & -.098 \\ -.017 & -.038 \\ -.227 & -.222 \\ -.017 & -.020 \\ -.299 & -.301 \\ -.613 & -.611 \\ -.465 & -.46 \\ -.537 & -.539\end{array}$

$\begin{array}{ll}.005 & -.006 \\ -.099 & -.0111 \\ -.044 & -.040 \\ -.228 & -.256 \\ -.019 & -.026 \\ -. .342 & -. .347 \\ -.608 & -.607 \\ -.465 & -.463 \\ -.539 & -. .544\end{array}$

-.008
-.096
-.045
-.054
-.027
.- .324
-.007
-.456
-.531

-.008
-.099
-.038
-.248
-.035
-.324
-.611
-.461
-.535

acontrols are: 1-Upset with Leaders, 2-U.S. Gov't. Unjust, 3-Liberal or Radical, 4-Age, 5-Financial Difficulty.

${ }^{b}$ Coefffcients are Kendall Partial Rank Correlation Coefficients and represent an extension of the formula:

$$
\tau_{x y+z}=\frac{\tau_{x y}-{ }^{\top} z y^{\top} z x}{\sqrt{\left(1-{ }^{\top} z y^{2}\right)\left(1-{ }^{\top} z x^{2}\right)}}
$$

The specific Kendall Tau used for total correlations is $\tau_{b}$. 
TABLB XIII

PARTIAL RANK CORRELATIONS BETWEEN POWERLESSNESS AND MEANINGLESSNESS

IN EDUCATION, CONTROLLING FOR SELECTED INOEPENDENT VARIABLESA

(Females Only)

\begin{tabular}{|c|c|c|c|c|c|c|c|}
\hline & \multirow[b]{2}{*}{$\tau_{x y}$} & \multicolumn{4}{|c|}{$\begin{array}{l}\text { PARTIAL RANK CORRELATIONS } \\
\text { (Listwise Deletion) }\end{array}$} & \multirow[b]{2}{*}{$\tau_{x y} \cdot 1,2,3,4,5$} & \multirow[b]{2}{*}{$\begin{array}{l}\text { Number of } \\
\text { Respondents }\end{array}$} \\
\hline & & $\tau_{x y \cdot 1}$ & ${ }^{7} x y \cdot 1,2$ & ${ }^{\top} x y \cdot 1,2,3$ & $\tau_{x y}=1,2,3,4$ & & \\
\hline \multicolumn{8}{|c|}{ Alienation in Education } \\
\hline $\begin{array}{l}\text { Q15 with } 014 \\
\text { Q15 with Q18 } \\
\text { Q16 with Q14 } \\
\text { Q16 with Q18 } \\
\text { Q19 with Q14 } \\
\text { Q19 with Q18 }\end{array}$ & $\begin{array}{l}-.447 \\
-.538 \\
-.358 \\
-.526 \\
-.404 \\
-.471\end{array}$ & $\begin{array}{l}-.424 \\
-.527 \\
-.358 \\
-.528 \\
-.411 \\
-.466\end{array}$ & $\begin{array}{l}-.419 \\
-.520 \\
-.312 \\
-.492 \\
-.387 \\
-.457\end{array}$ & $\begin{array}{l}-.435 \\
-.520 \\
-.314 \\
-.488 \\
-.415 \\
-.454\end{array}$ & $\begin{array}{l}-.430 \\
-.524 \\
-.314 \\
-.499 \\
-.413 \\
-.462\end{array}$ & $\begin{array}{l}-.429 \\
-.524 \\
-.314 \\
-.499 \\
-.389 \\
-.443\end{array}$ & $\begin{array}{l}(58) \\
(45) \\
(57) \\
(42) \\
(53) \\
(31)\end{array}$ \\
\hline
\end{tabular}

"Controls are: 1-Expectations in Education Unmet, 2-Apathetic about Coursework, 3-Socfal Science-Liberal Arts iajor, 4-Age, 5-Financlai Difftculty,

bee footnote Table XII. 
TABLE XIV

PARTIAL RANT CORRETLATIONS BETWEEN POLITICAL POWERLESSWESS AND MRANTATGLESSNESS, CONTROLIING FOR SELECTED INDEPENDENT VARTABLES

(rales Oaly)

\begin{tabular}{|c|c|c|c|c|c|c|c|}
\hline & \multirow[b]{2}{*}{$I_{x y}$} & \multirow[b]{2}{*}{$\tau_{x y \cdot i}$} & \multicolumn{3}{|c|}{$\begin{array}{l}\text { PARTIAL RANK CORRELATIONS } \\
\text { (Listwise Deletion) }\end{array}$} & \multirow[b]{2}{*}{$\tau_{x y \cdot 1,2,3,4,5}$} & \multirow[b]{2}{*}{$\begin{array}{l}\text { Number of } \\
\text { Respondents }\end{array}$} \\
\hline & & & $\tau_{x y \cdot 1,2}$ & $\tau_{x y \cdot 1,2,3}$ & $\tau_{x y \cdot 1,2,3,4}$ & & \\
\hline \multicolumn{8}{|c|}{ Alienation in Polities } \\
\hline $\begin{array}{l}\text { Q3 with Q2 } \\
\text { Q3 with Q5 } \\
\text { Q3 with Q6 } \\
\text { Q1 with Q2 } \\
\text { Q1 with } 05 \\
\text { Q1 with } 06 \\
\text { Q4 with Q2 } \\
\text { Q4 with Q5 } \\
\text { Q4 with Q6 }\end{array}$ & $\begin{array}{l}-.144 \\
-.457 \\
-.292 \\
-.056 \\
-.261 \\
-.585 \\
-.484 \\
-.632 \\
-.592\end{array}$ & $\begin{array}{l}-.163 \\
-.465 \\
-.284 \\
-.057 \\
-.269 \\
-.601 \\
-.489 \\
-.634 \\
-.532\end{array}$ & $\begin{array}{l}-.162 \\
-.483 \\
-.268 \\
-.070 \\
-.307 \\
-.623 \\
-.493 \\
-.652 \\
-.531\end{array}$ & $\begin{array}{l}-.162 \\
-.483 \\
-.267 \\
-.060 \\
-.312 \\
-.634 \\
-.494 \\
-.654 \\
-.523\end{array}$ & $\begin{array}{l}-.763 \\
-.468 \\
-.267 \\
-.055 \\
-.308 \\
-.640 \\
-.495 \\
-.653 \\
-.531\end{array}$ & $\begin{array}{l}-.161 \\
-.468 \\
-.300 \\
-.094 \\
-.302 \\
-.608 \\
-.493 \\
-.650 \\
-.518\end{array}$ & $\begin{array}{r}(64) \\
(67) \\
(65) \\
(30) \\
(36) \\
(29) \\
(39) \\
(45) \\
(35)\end{array}$ \\
\hline
\end{tabular}

See footnote Table sIr.

bee footnote Table III. 
TABLE XV

PARTIAL RANK CORRELATIONS BETWEEN POWERLESSNESS AND MEANINGLESSNESS

IN EDUCATION, CONTROLLING FOR SELECTED INDEPENDENT VARIABLES ${ }^{2}$

(Males Oniy)

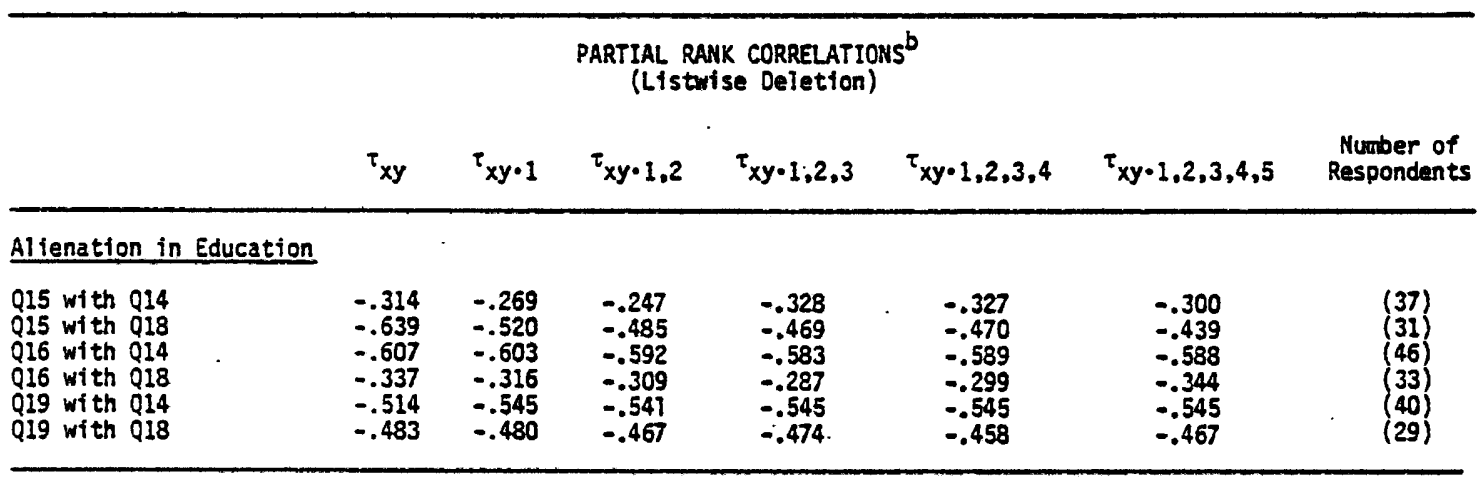

${ }^{a}$ See footnote Table XIII.

bsee footnote Table XII. 
being liberal or radical, and having financial difficulties in the last year often act to suppress the "true" correlation between powerlessness and meaninglessness among women. ${ }^{1}$ Still these effects are rather slight, since the average increase is absolute correlation is only .024.

Yet, unlike the correlations between the previous powerlessness measures (voting for national leaders is useless, the two-party system offers real alternatives) and political meaninglessness, the fifth-order partials for Q4 (being aware of political issues matters) exhibit a slight loss in correlation over the zero-order correlation, with an average decline in correlation of only .003 .

In one Instance, moreover, a slight "distortion" in the relationship between alienation toward political parties and the government occurs in the fifth-order partial (Q3 with Q2). Although the zero-order correlation is weak but positive, the fifthorder partial is weak but negative. This indicates the direction of the zero-order correlation has been distorted by positive correlations between the measures and several independent variables, perception of government, liberal or radical identification, and age. Once such confounding influences are

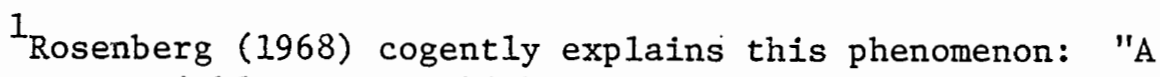
suppressor variable is one which weakens a relationship, which conceals its true strength. In some cases, it may weaken the relationship to the point of causing its complete disappearance, but this situation will not always obtain. So long as it damps down or attenuates the full extent of the relationship, it poses the danger of misleading interpretations" (Rosenberg, 1968:85). 
controlled for, the positive zero-order correlation proves to be spurious and the true negative correlation becomes evident. ${ }^{1}$

Furthermore, in 8 out of 9 instances the fifth-order correlations are virtually the same as their zero-order correlations (Table XII). This suggests, for females at least, the negative partial correlations are evidently more a reflection of the non-relatedness of alienation dimensions than of the effects of independent variables, particularly those controlled for. The degree of correlation, moreover, breaks down into three categories: non-correlations, modestly negative correlations, and moderately negative correlations. The mean fifth-order correlation is -.262 . But what remains most crucial is the direction of the coefficients: all are negative. Since the null hypothesis predicts just the opposite, there is no point in even considering statistical tests of significance. For as Blalock (1979) points out:

A very minimal (but legitimate) question the skeptic may raise, whenever one claims that a predicted relationship has been found, is whether the relationship is due to sampling error. . . But if we have obtained a relationship that is opposite to that predicted we have, in effect, already lost the argument with the skeptic. Therefore there is no point in making a significance test of the null hypothesis (Blalock, $1979: 164)$.

To continue with the findings, one can see the correlations in Table XIII are far more homogeneous. After controlling for unmet

$1_{\text {Rosenberg (1968) adds: "Perhaps the most striking example }}$ of how test factors may avert the danger of misleading conclusions appears when we examine what, for want of a better term, might be called 'distorter' variables. A distorter variable reveals that the correct interpretation is precisely the reverse of that suggested by the original data" (Rosenberg, 1968:94). 
expectations, apathy in college, major, and financial difficulty, the zero-order correlations decline in correlation an average of only .024. Again, age seems to have little or no effect, while apathy generally has the "most" effect in reducing the correlation. Nearly all alienation-in-education fifth-order partials are moderately negative, with a mean correlation of -.433 . Thus more evidence now exists to reject the null hypothesis, at least for women, that powerlessness and meaninglessness are highly and positively correlated.

As Table XIV further indicates, 56 percent of the fifth-order partials for men are moderately negative correlations, while the remainder are modestly or weakly so. The mean fifth-order partial is -.399. All fifth-order partials are virtually the same as their zero-order correlations, suggesting again that correlations are more reflective of the non-relatedness of alienation dimensions than of correlations with independent variables. However, 8 out of 9 zeroorder correlations exhibit the slight effects of suppressor variables, with being upset at leaders, perception of the government, and financial difficulty often suppressing the "true" correlation between powerlessness and meaninglessness. But in 5 out of 9 partial correlations, age, financial difficulty, and being a liberal or radical are superfluous.

Regarding alienation in education for men (Table XV), 4 out of 6 fifth-order partials reveal an average decline in correlation of .062 over the zero-order correlations. The mean fifth-order partial is -.447 . Unmet expectations and apathy in college account for some 
of the non-relatedness between powerlessness and meaninglessness, while social science-liberal arts major tends to mask the "true" correlations. Age, on the other hand, is largely superfluous.

Consequently, for men as well as for women, evidence exists to reject Operational Hypothesis I. That is, perception of powerlessness is not a condition for perception of meaninglessness or vice versa, especially in politics or education. There are, of course, 15 possible combinations by sex between measures of alienation in politics and in education which have not been reported, since the presentation of at least 150 more correlations would only belabor the point. All unreported fifth-order partials are negative, regardless of sex, and most moderately so.

\section{ALIENATION IN POLITICS AND EDUCATION}

Regarding the null hypothesis that the more alienation in politics, the more alienation in education, Table XVI preliminarily disconfirms this generalization hypothesis. ${ }^{1}$ For instance, regardless

$1^{1}$ Tables X-XV, only individual alienation items were utilized since Operational Hypothesis I deals with whether or not particular alienation dimensions are positively related. However, Operational Hypotheses II and III deal with either institutional alienation or institutional perceptions of power and authority; thus, Tables XVI-XXII utilized alienation scale scores. Although construction of the scale scores was rather complicated (since exceptions to the rule were necessary when misclassification or missing data became a problem), a simple description of the scale construction should cover the majority of cases. In short, alienation items were scored 1-5, with the latter score indicative of alienation. Since each scale comprised three alienation items, 15 summated scores were possible. Thus, summated scores 1-6 (includes three 1's, or three 2's or other combinations exclusive of two $3^{\prime} \mathrm{s}$ plus 1 ) indicate the not alienated, while scores 7-9 (includes three $3^{\prime} \mathrm{s}$, or two $3^{\prime} \mathrm{s}$ plus 2 , or other 
TABLE XVI

ZERO-ORDER RANK CORRELATIONS BETWEEN INSTITUTIONAL

POWERLESSNESS AND MEANINGLESSNESS AND THE

PROPORTION TOTALLY ALIENATED BY SEX ${ }^{\mathrm{a}}$

(Respondents in Parentheses)

POLITICAL ALIENATION

ALIENATION

IN EDUCATION

Power lessness

Meaninglessness

Males Females

MaTes

Females

Powerlessness

Percent:

Correlation:

-.42
$(45)$

3
-.24
$(66)$

-
-.35
$(44)$

4
-.28
$(55)$

Meaninglessness

Percent:

Correlation:
17
-.45
$(41)$

16

$-.25$

(62)

13

$-.67$

(39)

20

$-.32$

(46)

${ }^{a}$ See footnote Table XI. 
of sex, all correlations are negative and no more than 20 percent of the alienated experience both powerlessness and meaninglessness, or total alienation. The mean correlation for males is -.47 , while -.27 for females. Women, moreover, are slightly more likely than men to experience total alienation, partially accounting for the differential in mean correlation. ${ }^{1}$

It is of course possible the negative zero-order correlations are spurious. To assess this, partial correlations were computed by hand (Table XVII). Regarding males, the mean fifth-order partial correlation is -.430 . Partial correlations between political alienation and meaninglessness in education show a very slight average decline in correlation of only .01 over the zero-order correlations, indicating the controls have little effect. On the other hand, correlations between political alienation and powerlessness in education expand slightly due to suppression, with the average correlation increasing by .018 over the zero-order correlations. Yet the partial correlation between political powerlessness and powerlessness in education change almost imperceptibly, while the last test, political meaninglessness with powerlessness in eduation is

combinations exclusive of two 2's plus 3) indicate the ambivalent, while scores 10-15 (includes three $5^{\prime} \mathrm{s}$ : or two $5^{\prime} \mathrm{s}$ plus 4 , or other comibinations exclusive of two 3 's plus 4) Indicate the alienated. The computer language necessary to develop this summation system took several weeks to perfect and will be made available upon request.

${ }^{1}$ Women are also slightly more likely to experience total ambivalence (that is, ambivalent toward both politics and education) than men. 
IABLE IVII

PARTIAL RANK CORRELATIONS BETWEEN INSTITUTIONAL POWERLESSNESS AND MEANINGLESSNESS, CONTROLLING FOR SELECTED INDEPENDENT VARIABLES BY SEX ${ }^{a}$

\begin{tabular}{|c|c|c|c|c|c|c|c|}
\hline & \multirow[b]{2}{*}{$\tau_{x y}$} & \multirow[b]{2}{*}{$\tau_{x y-1}$} & \multicolumn{3}{|c|}{$\begin{array}{l}\text { PARTIAL, RANK CORRELATIONSC } \\
\text { (Listwise Deletion) }\end{array}$} & \multirow[b]{2}{*}{$\tau_{x y=1,2,3,4,5}$} & \multirow[b]{2}{*}{$\begin{array}{l}\text { Number of } \\
\text { Respondents }\end{array}$} \\
\hline & & & $\tau_{x y}=1,2$. & $\tau_{x y} \cdot 1,2,3$ & $\tau^{\tau} x y=1,2,3,4$ & & \\
\hline $\begin{array}{l}\text { Males } \\
\text { Polpow with Edmean } \\
\text { Polmean with Ednean } \\
\text { Polpow with Edpow } \\
\text { Polmean with Edpow }\end{array}$ & $\begin{array}{l}-.423 \\
-.559 \\
-.415 \\
-.309\end{array}$ & $\begin{array}{l}-.413 \\
-.559 \\
-.415 \\
-.299\end{array}$ & $\begin{array}{l}-.409 \\
-.556 \\
-.413 \\
-.325\end{array}$ & $\begin{array}{l}-.398 \\
-.543 \\
-.411 \\
-. .324\end{array}$ & $\begin{array}{l}-.404 \\
-.547 \\
-.417 \\
-.345\end{array}$ & $\begin{array}{l}-.406 \\
-.557 \\
-.417 \\
-.342\end{array}$ & $\left.\begin{array}{l}\left(\begin{array}{l}35 \\
36\end{array}\right) \\
(39) \\
39\end{array}\right)$ \\
\hline $\begin{array}{l}\text { Females } \\
\text { Polpow with Edmean } \\
\text { Polmean with Edmean } \\
\text { Polpow with Edpow } \\
\text { Polmean with Edpow }\end{array}$ & $\begin{array}{l}-.180 \\
-.298 \\
-.211 \\
-.207\end{array}$ & $\begin{array}{l}-.225 \\
-.352 \\
-.249 \\
-.222\end{array}$ & $\begin{array}{l}-.210 \\
-.352 \\
-.258 \\
-.238\end{array}$ & $\begin{array}{l}-.198 \\
-.375 \\
-.259 \\
-.242\end{array}$ & $\begin{array}{l}-.192 \\
-.305 \\
-.270 \\
-.238\end{array}$ & $\begin{array}{l}-.190 \\
-.302 \\
-.279 \\
-.259\end{array}$ & $\begin{array}{l}(56) \\
(38) \\
(59) \\
(46)\end{array}$ \\
\hline
\end{tabular}

acontrols are: 1 - Apathetlc about coursework; 2 - Social Sefence-Liberal Arts major; 3 - Expectations in education unmet (males only), Upset with leaders (females only); 4 - Liberal or radical; 5 - Loss of community.

bATienation indicators are: Polpow - Political Powerlessness; Polmean - Polftical Meaninglessness; Edpow - Powerlessness in Education; Edmean - Meaninglessness in Education.

CKendall Partial Rank Correlation Coefficients. 
indicative of dampening effects due to the individual's major and liberal-radical identification.

Examining institutional alienation among females, however, one notices all zero-order correlations are affected by suppressor variables. The mean fifth-order correlation is -.258 , which is 40 percent less than the average fifth-order partial for men. Nonetheless, the average increase in correlation is .034 . Apathy in college, as one would expect, suppresses the "true" correlations the most, confirming the context-specific argument that alienation and, in this case, apathy are responses to specific situations and not free-floating psychic states. Interestingly, loss of community, among both men and women, is largely superfluous. While this fact alone does not refute the theory that loss of community causes alienation, it does call into question the effect loss of community has on institutional alienation. Likewise, at least with regard to alienation in politics and education, the generalization hypothesis deserves rejection, since the evidence accumulated in this study indicates total alienation is even rarer across institutions than within. Therefore, the prediction the more alienation in politics the more alienation in education seems quite fallacious.

ALIENATION, POWER RELATIONS, AND LOSS OF COMMUNITY

Although Operational Hypotheses I and II have received disconfirmation, the crux of Nisbet's theory of alienation, that in power relations loss of community is positively associated with 
alienation, may yet prove valid. Table XVIII, for instance, offers preliminary support for such a theory. ${ }^{1}$

Now as Table XVIII illustrates, those perceiving the U.S. Government as an unjust system of government are on the average 4.2 times more likely to appear rootless (those who feel some or much loss of community and intense alienation) than those perceiving authority relations in the political arena. Moreover, with one exception, correlations between alienation and loss of community are higher in the former group than in the latter. For instance, the average correlation is .32 among the PPR, but only .13 among the PAR. Regarding education, the results are mixed. While the average proportional differential is 2.2 (meaning those who perceive power relations are more likely to feel alienation and loss of community than those who perceive authority relations), the correlations are as great or greater in the PAR than in the PPR. A number of explanations may account for this quirk: 1) the fact only 36 percent of the respondents answered the measure may have adversely affected the correlations, by allowing self-selection to determine the composition of the PPR and PAR; 2) the correlations may prove to be distortions once statistical controls are performed; 3 ) the higher correlations among the PAR may result from their experiencing more ambivalence, especially since the proportion rootless among this group is quite rare.

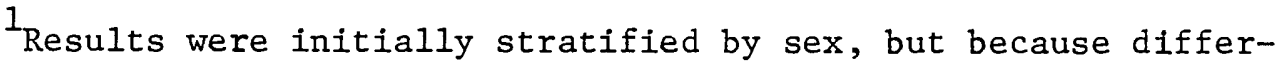
ences were negligible such stratification was deemed unnecessary and trivial. 
TABLE XVIII

ZERO-ORDER RANK CORRELATIONS BETWEEN ALIENATION AND LOSS OF COMMUNITY AND THE PROPORIION ROOTLESS BY PERCEPTIONS OF POWER AND AUTHORITY RELATIONS ${ }^{a}$

\begin{tabular}{|c|c|c|c|c|c|c|c|}
\hline & \multicolumn{7}{|c|}{ POWER AND AUTHORITY RELATIONS } \\
\hline & $\frac{\text { Perceive }}{\text { Yes }}$ & U.S. & $\frac{\text { Gov't Unjust }}{\text { TotaT }}$ & \multicolumn{2}{|c|}{$\frac{\text { Perceive Faculty }}{\text { Yes }}$} & \multicolumn{2}{|c|}{$\frac{\text { Control Unfair }}{\text { Total }}$} \\
\hline \multicolumn{8}{|l|}{ Polpow with Loss } \\
\hline $\begin{array}{l}\text { Percent: } \\
\text { Correlation: }\end{array}$ & $\begin{array}{c}51 \\
.32 \\
(67)\end{array}$ & $\begin{array}{c}9 \\
.13 \\
(226)\end{array}$ & $\begin{array}{r}18 \\
.25 \\
(293)\end{array}$ & $\begin{array}{c}30 \\
.30 \\
(23)\end{array}$ & $\begin{array}{r}13 \\
.26 \\
(91)\end{array}$ & & $\begin{array}{c}17 \\
(i 14)\end{array}$ \\
\hline \multicolumn{8}{|l|}{ Polmean with Loss } \\
\hline $\begin{array}{l}\text { Percent: } \\
\text { Correlation: }\end{array}$ & $\begin{array}{c}31 \\
.51 \\
(70)\end{array}$ & $\begin{array}{c}9 \\
.07 \\
(226)\end{array}$ & $\begin{array}{c}14 \\
.22 \\
(296)\end{array}$ & $\begin{array}{c}17 \\
.26 \\
(23)\end{array}$ & $\begin{array}{c}8 \\
.07 \\
(91)\end{array}$ & & $\begin{array}{r}10 \\
.13 \\
(714)\end{array}$ \\
\hline \multicolumn{8}{|l|}{ Edpow with Loss } \\
\hline $\begin{array}{l}\text { Percent: } \\
\text { Correlation: }\end{array}$ & $\begin{array}{l}28 \\
.28 \\
(61)\end{array}$ & $\begin{array}{r}99 \\
(207 \\
(206)\end{array}$ & $\begin{array}{r}13 \\
.15 \\
(267)\end{array}$ & $\begin{array}{c}18 \\
.06 \\
(22)\end{array}$ & $\begin{array}{c}7 \\
.18 \\
(91)\end{array}$ & & $\begin{array}{c}9 \\
(118 \\
(113)\end{array}$ \\
\hline \multicolumn{8}{|l|}{ Edmean with Loss } \\
\hline $\begin{array}{l}\text { Percent: } \\
\text { Correlation: }\end{array}$ & $\begin{array}{r}19 \\
.16 \\
(69)\end{array}$ & $\begin{array}{r}4 \\
.25 \\
(223)\end{array}$ & $\begin{array}{r}8 \\
.25 \\
(292)\end{array}$ & $\begin{array}{c}9 \\
.15 \\
(23)\end{array}$ & $\begin{array}{r}5 \\
31 \\
(91)\end{array}$ & & $\begin{array}{c}6 \\
(i 14)\end{array}$ \\
\hline
\end{tabular}

a Proportion rootless refers to those experiencing loss of community in 2 to 4 measured realms - the family, the university, the state, the nation - and powerlessness or meaninglessness.

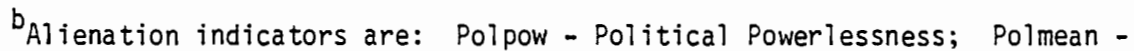
Political Meaninglessness; Edpow - Powerlessness in Education; Edmean Meaninglessness in Education.

${ }^{\mathrm{C}}$ Spearman Rank Correlation Coefficients. 
The first explanation, as Table XIX demonstrates, can be easily dismissed. Those who chose to evaluate the fairness of faculty authority are for the most part no different than those who chose not to. However, more non-evaluators work full-time than evaluators, leading to less perceptions of financial difficulty among the former. of course the fact evaluators are more likely to have enrolled in more classes explains why fewer work full-time, even though no difference exists between the two groups as regards working at all. The crucial test though of the first explanation is whether or not evaluators are signfficantly more alfenated than non-evaluators. Indeed if either were more or less alienated, then using the fairness item to measure perceptions of power or authority relations would be incorrect. This would mean Operational Hypothesis III could not be tested on alienation in education, but only on alienation in politics. But as the results illustrate, evaluators are neither more nor less alienated in education or politics than non-evaluators. Clearly then, given that evaluators are somewhat more likely to have attended the university longer, responses to the fairness measure seem to reflect familiarity, longevity, and lack of competing involvements, but certainly no substantive bias. Therefore, the Low response rate in the fairness measure does not explain away the reported correlations and must be rejected as an explanation, since it is not a plausible one.

Table Xx, moreover, evaluates the general feasibility of the second explanation through partial correlations. Under perceptions of power relations the average fourth-order partial is .287 , with 
TABLE XIX

CHARACTERISTICS OF STUDENTS WHO EVALUATED THE FAIRNESS

OF FACULTY AUTHORITY OR WHO RESPONDED DON'T KNOW

\begin{tabular}{|c|c|c|c|}
\hline & \multicolumn{3}{|c|}{ STUDENTS } \\
\hline$\cdot$ & $\begin{array}{l}\text { Evaluators } \\
(114)\end{array}$ & $\begin{array}{l}\text { Non-Evaluators } \\
(192)\end{array}$ & $\begin{array}{l}\text { Level of } \\
\text { Significance }\end{array}$ \\
\hline Female & $51 \%$ & $58 \%$ & n.s. \\
\hline White & $83 \%$ & $89 \%$ & n.s. \\
\hline Average Age & 31.9 & 31.6 & n.s. \\
\hline Married & $53 \%$ & $56 \%$ & n.s. \\
\hline Live Alone & $23 \%$ & $23 \%$ & n.s. \\
\hline Have Children & $50 \%$ & $48 \%$ & n.s. \\
\hline Currently Working & $85 \%$ & $89 \%$ & n.s. \\
\hline Work Full-Time & $58 \%$ & $78 \%$ & .001 \\
\hline $\begin{array}{c}\text { Financial Difficulty } \\
\text { (median) }\end{array}$ & 3.8 & 2.8 & .04 \\
\hline Good Health & $85 \%$ & $86 \%$ & n.s. \\
\hline Parents-college degree & $48 \%$ & $46 \%$ & n.s. \\
\hline Median credits enrolled & 6.1 & 3.3 & .004 \\
\hline Median quarters enrolled & 7.3 & 5.9 & .01 \\
\hline \multicolumn{4}{|l|}{ Median Perception Scores ${ }^{b}$} \\
\hline Apathetic about coursework & 3.5 & 4.0 & n.s. \\
\hline Upset with national leaders & 4.9 & 4.9 & n.s. \\
\hline Consider U.S. Gov't Unjust & 3.3 & 3.5 & n.s. \\
\hline \multicolumn{4}{|l|}{ Median Alienation Scores ${ }^{c}$} \\
\hline Political Powerlessness & 7.6 & 7.7 & n.s. \\
\hline Political Meaninglessness & 7.1 & 7.3 & n.s. \\
\hline Powerlessness in Education & 5.8 & 5.4 & n.s. \\
\hline Meaninglessness in Education & 5.1 & 5.5 & n.s. \\
\hline
\end{tabular}

${ }^{a}$ Chi-square test for independence computed on percentage differences (2x2 tables), while Mann-Whitney significance test computed on average and median differences.

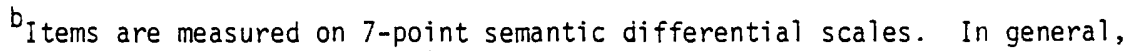
the nigher the score, the more dissatisfaction.

${ }^{C}$ Alienation indicators, except for powerlessness in education, measure alienation on 15-point scales. A value of 10 or more indicates alienated, while 5 or less indicates not al ienated. For powerlessness in education, alienation is measured on a 10-point scale. A value of 7 or more indicates alierated, while 4 or less indicates not alienated. 
TABLE $8 X$

PARTIAL RANK CORRELATIONS BETWEEN ALIENATION AND LOSS OF COMMUNITY, CONTROLLING FOR SELECTED INDEPENDENT VARIABLES ${ }^{a}$

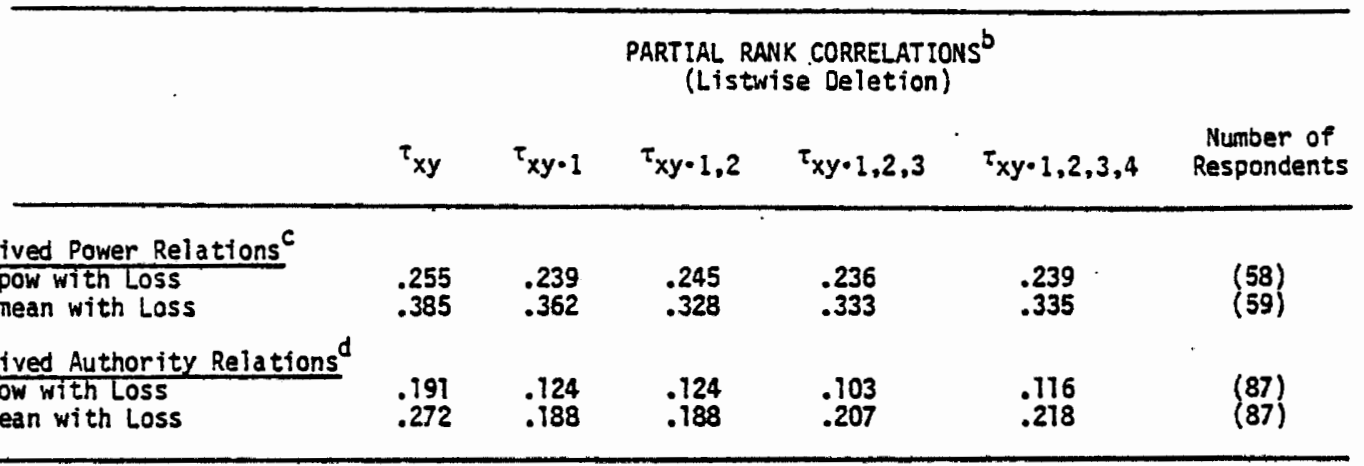

\section{${ }^{a}$ Controls under Perceived Power Relations are: 1 - Live alone, 2 - Liberal or radical,} 3 - Upset with leaders, 4 - Member of voluntary association.

Controls under Perceived Authority Relations are: 1 - Expectations in education unmet.

2 - Apa thetic about coursework, 3 - Live alone, 4 - Member of voluntary association.

${ }^{b}$ Coefficients are Kendall Partial Rank Correlation Coeffictents. The specific Kendall Tau used for total correlations is $\tau_{b}$.

CPerceived Power Relations was measured by the question: "As a systen, how just or unjust do you think the U.S. Government is?" A 7-point semantic differentfal scale, with "very just" and "very unjust" at the poles, comprised the response choices. "Very just" was assigned a value of 1 , while "very unjust" a value of 7 . Those respondents who positioned thenselves 5 or above on the scale are considered to perceive national politics as a power relation between the government and the individual.

'Perceived Authority Relations was measured by the question: "Do you consider (this university's) departmental system a fair or unfair way to govern things?" Response choices were also ordered along a 7-point semantic differential scale, with "very fair" and "very unfair" at the poles. "Very fair" was assigned a value of 1. while "very unfalr" a value of 7. Those respondents who positioned themselves 4 or below on the scale are considered to perceive the university as an authority relation between the institution and the individual. 
living alone and liberal-radical identification affecting correlational change the most. Membership in a voluntary association (professional, community, or political groups), however, appears superfluous.

Yet when perceptions of authority relations are considered, living alone still affects the correlations the most, but liberalradical identification becomes superfluous, while voluntary association tends to suppress the "true" correlations. And although the average fourth-order partial of .167 is 42 percent weaker than the correlation between alienation and loss of community under perceptions of power relations, the relationship is still positive--which seems to contradict Nisbet's theory of alienation. Of course, this contradiction may only be an apparent one, especially if ambivalence rather than alienation accounts for these positive associations.

To examine the plausibility of the ambivalence argument, Kruskal-Wallis Analysis of Variance was performed (Table XXI). The results are quite clear: 1) in power relations, the more loss of community, the more alienation; but 2) in authority relations, the more loss of community, the more ambivalence. For instance, under perceptions of power relations, those feeling little or no loss of community possess a median level of powerlessness in politics of 8.0 (in the ambivalence range), while those feeling much loss have a median level of powerlessness in politics of 10.7 (in the alienation range). But under perceptions of authority relations, those feeling little or no loss and those feeling much loss possess median 


\section{TABLE}

KRUSTAL-WALIIS ANALYSIS OF VARTANCE ON ALIEMTATION AND LOSS OF COMMOIITY

BP PERCEPTIONS OF POWER AND AUTEORITY RELATIOWS

(Medtan Response) a

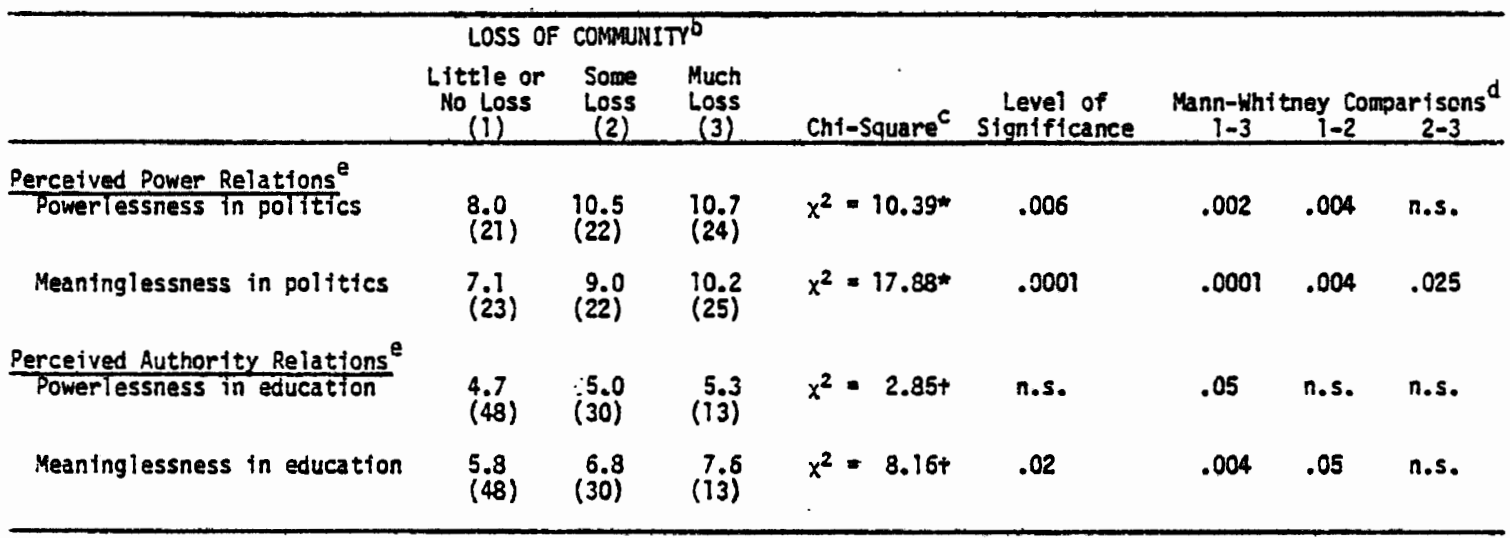

alienation scale values, except for powerlessness in education, are: 1-5 refers to the not alienated, 6-9 refers to the ambivalent, and 10-15 refers to the al ienated. Scale values for powerlessness in education are: 1-4 refers to the not alienated, 5-6 refers to the ambivalent, and 7-10 refers to the alienated.

bespondents were asked if they generally experfence a sense of community in 4 realms - the family, the university, the state, the nation. "Little or no loss" refers to 1 or less "no" responses (with "no" refering to loss of community), "some loss" refers to 2 "no" responses, while "much loss" refers to 3 or more "no" responses.

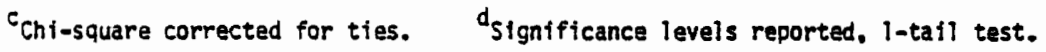

esee footnotes Table $\mathrm{XIX}$. *Fail to reject hypothesis. *Ambivalence trend. 
levels of alienation in education in the not alienated or ambivalent ranges.

Table XXII, moreover, further clarifies the issue. A perfect monotonic relationship exists between alienation and loss of community under power relations, with those feeling much loss 2.4-3.3 times more likely to be alienated than those feeling little or no loss. Regarding authority relations, however, no significant differences in alienation characterize those feeling much loss and little or no loss--exactly what one would expect if Nisbet's theory were correct. Therefore, the evidence seems abundant enough to affirm Operational Hypothesis III and suggests the core of Nisbet's theory of alienation is valid. 
TABLE XXII

ALIENATION AND LOSS OF COMMUNITY BY PERCEPTIONS

OF POWER AND AUTHORITY RELATIONS

(Percent Alienated)

\begin{tabular}{lccc}
\hline & \multicolumn{3}{c}{ LOSS OF COMMUNITY $^{\mathrm{a}}$} \\
& $\begin{array}{c}\text { Little or } \\
\text { No Loss }\end{array}$ & $\begin{array}{c}\text { Some } \\
\text { Loss }\end{array}$ & $\begin{array}{c}\text { Much } \\
\text { Loss }\end{array}$ \\
\hline Perceived Power Relations & & & \\
\hline Powerlessness in politics & $33^{c /}$ & $68 \%$ & $79 \%$ \\
Meaninglessness in politics & $(27)$ & $(22)$ & $(24)$ \\
Perceived Authority Relations & $17 \%$ & $41 \%$ & $56 \%$ \\
Powerlessness in education & $(23)$ & $(22)$ & $(25)$ \\
Meaninglessness in education & & & \\
& $(48)$ & $(30)$ & $(13)$ \\
& $4 \%$ & $10 \%$ & $15 \%$ \\
\hline
\end{tabular}

${ }^{a}$ See footnote Table $\mathrm{xx}$.

$b_{\text {See footnote Table XIX. }}$ 
CHAPTER V

\section{DISCUSSION}

\section{RELATION OF FINDINGS TO PREVIOUS RESEARCH}

To be sure, powerlessness and meaninglessness are non-related types of alienation. But the question remains not so much why this is so, but why the contradiction with previous research? The answer appears primarily to be that a methodological fallacy, repeated in study after study, has precluded valid tests of Operational Hypothesis I, or hypotheses similarly fashioned.

For instance, research undertaken by Dean (1961), Middleton' (1963), and Neal et al. (1976) overlook the fact positive correlations between powerlessness and meaninglessness, or other types of alienation, are based on the total sample of respondents. Whether or not an individual who experienced powerlessness also experienced meaninglessness was not empirically tested, rather only the statements, or items as items, were tested. Subsequently, the reported positive correlations may have resulted from two possibilities: 1) the majority of respondents may have indicated "not alienated" on both, or all, types of alienation; or 2) the majority of respondents may have indicated "alienated" on both, or all, types of alienation. It seems evident, however, that the former is more plausible and therefore more likely. 
As this survey of graduate students illustrates, the majority of respondents indicated they were either not alienated or ambivalent, while the proportion of the totally alienated averaged only 17 percent. $^{1}$ However, if one reflects upon a more volatile time in recent history--such as the Vietnam War era in America--when students were widely considered alienated, one encounters evidence showing only about 32 percent of all American college students were alienated in 1970, while more than twice that proportion of New Left students were (Yankelovich, 1972). Thus, even during a period of mass polarization, alienation did not appear as a general phenomenon, though certainly among leftists alienation seemed widespread. But more to the point, indications are research out of the unidimensional school has tended to commit the methodological fallacy that correlations between statements of alienation, regardless of individual response, are equivalent to correlations between states of alienation.

Moreover, other research hints that powerlessness and meaninglessness are non-related in other settings and among different respondents. For instance, Seeman (1972) studied 400 male workers in Los Angeles and 400 male workers in Paris, France in the spring of 1967. His purpose was to determine:

1) what kinds of alienation are problematic;

2) how generalizable, or thoroughgoing, is alienation within the individual's life and across class-lines;

${ }^{1}$ Incidentally, when correlations are based on all respondents in this survey, all statements of powerlessness are positively correlated with all statements of meaninglessness. 
3) what level of alienation triggers either political engagement or disengagement;

4) how does alfenation bear upon the worker's integration in organizational life; and

5) whether or not alienation is associated with left-right polarization.

As such, the scope of his approach not only bears upon two of the three hypotheses tested in the present study, but may also add a measure of support for the related findings.

Although Seeman did not directly test the unidimensional hypothesis, evidence he offers does suggest powerlessness and meaninglessness are generally non-related types of alienation. As Table XXIII indicates, even after controlling for education, occupation, and nationality, in only 1 out of 8 comparisons is it definitely plausible to argue powerlessness and meaninglessness are positively related. French manual workers who are poorly educated appear to be the only group where a majority may experience both powerlessness and meaninglessness. In the United States, however, such dimensions of alienation seem non-related for manual workers and negatively related for non-manual workers. On the other hand, except for the poorly educated manual workers, powerlessness and meaninglessness generally appear negatively related for French workers. Consequently, Seeman concludes alienation in pre-crisis France was not diffuse. He elaborates:

The alienation depicted here is remarkable for its lack of diffusion. It is the sense of powerlessness that emerges as the key form of allenation in pre-crisis France; and this powerlessness was not diffuse in two 


\section{TABLE XXIIT}

RELATIONSHIP BETWEEN POWERLESSNESS AND MEANINGLESSNESS AMONG AMERICAN AND FRENCH WORKERS, CONTROLLING FOR EDUCATION, OCCUPATION, AND NATIONALITY: $1967^{\circ}$

(Percent Alienated)

\section{OCCUPATION}

Manua 7 American French

Non-Manua 1 American French

Low Education

Powerlessness

Meaninglessness

$53 \%$

57

$76 \%$

$52 \%$

$78 \%$

Number of Respondents

(61)

(136)

(132)

High Education

Powerlessness

Meaninglessness

$46 \%$

$64 \%$

38

$44 \%$

$64 \%$

50

(76)

28

17

Number of Respondents

(95)

(107)

$a_{\text {Powerlessness was indicated by agreement with the statement: }}$

"There is not much that I can do about most of the important problems that we face today." Meaninglessness was indicated by agreement with the statement: "Things have become so complicated in the world today that I really don't understand just what is going on."

SOURCE: Adapted from Melvin Seeman, 1972, "The Signals of '68: Alienation in Pre-Crisis France", American Sociological Review 37:385402. 
senses: (1) it was not highly correlated with a variety of other alienations: and (2) it was discriminating, in that it focused upon French society

itself as the arena of low control (Seeman, 1972:399).

Indeed, Seeman's work demonstrates the findings of this present survey, at least on the unidimensional hypothesis, probably apply to other groups and settings. Moreover, Seeman indicates, as does Bolton (1972), that where powerlessness and meaninglessness are or may be positively related, such an occurrence supports a contextspecific rather than a unidimensional model of alienation. ${ }^{1}$

With regard to the generalization hypothesis, Seeman (1967, 1972) found political alienation does not influence, or carry over into, work alienation. For instance, he argues that among American and French workers alienation does not represent "some generalized pall of discontent but [only] what we might call 'selective alienation'" (Seeman, 1972:389). On French workers, Seeman adds:

Far from reflecting a 'one-dimensional' man, the data depict a French worker whose alienations seem to be remarkably distinguishable for him. . . But he is not thereby expressing a thoroughgoing alienation (nor even generalized negativity) (Seeman, 1972:391).

To be sure, Seeman's finding that perceptions of powerlessness do not indicate generalized alienation but rather are relatively specific

${ }^{I_{\text {Seeman }}}$ found that the interaction of being French, poorly educated, and a manual worker contributed to a positive correlation between powerlessness and meaninglessness. On the other hand, Bolton's work may indicate that during the early $1960^{\prime} \mathrm{s}$ being a resident of a suburban university community and being a non-member of a peace-group may have contributed to feelings of more powerlessness and meaninglessness. However, since only 42 percent of non-members expressed "high powerlessness" and another 42 percent expressed "high meaninglessness," it seems doubtful that, in this instance, powerlessness and meaninglessness were positively correlated. 
to the political realm gives further support that the lack of generalized alienation among graduate students is not peculiar evidence confined to a narrow group.

Finally, although the loss of community theme has attracted the interest of urban sociologists, few, if any, have confined their attention to the effect of power relations on loss of community and alienation. For example, Fischer et al. (1977) summarize the theme as follows:

The decline-of-community thesis... presents the following historical argument: Modern society, through changes in its technology, economy, and ideology, has considerably eased the limits on individuals' choices of social relations. People have increasingly taken advantage of this freedom to form far-flung social networks, going beyond the bounds of older corporate groups. The end result, however, is that modern people have frequently sacrificed quality for quantity; they have formed many shallow, instrumental connections and lost the few deep, communal relations that once existed. Thus, the decline of community (Fischer et al., 1977:13).

This rendition of the loss of community argument, however, noticeably lacks any account of changes in the political state, and is especially deficient given the fact the authors regard Nisbet as "the most forceful contemporary proponent of the theory" (Fischer et al., 1977:7). It is no wonder then, that despite finding that membership in voluntary associations is more conducive to feelings of attachment to one's bedroom community than are institutional and kinship ties, the authors ultimately conclude that "neither our 
data nor those of others seem to support critical tests of the constraint and community propositions" (Fischer et a1., 1977:202). I

\section{THEORETICAL IMPLICATIONS OF FINDINGS}

That powerlessness and meaninglessness were found to be negatively related clarifies an important theoretical argument. Indeed, the notion that powerlessness and meaninglessness are unidimensional concepts that can be exchanged one for the other, especially if one is only interested in the general level of alienation, appears fallacious. This is so because exchangeability implies that a good deal of one conception, in this case powerlessness, is captured by its general counterpart, in this case meaninglessness. Yet if such were theoretically valid, powerlessness and meaninglessness would have, to be positively related. The fact the opposite was found renders unidimensional theory unsuitable, with regard to the dimensions tested.

Likewise, the theory of generalized alienation is called into question by the analysis of the second hypothesis. If alienation in one institutional setting, in this case politics, contributed to alienation in another institutional setting, in this case education, then a strong and positive relationship between types of alienation should have been observed. It was not. This indicates powerlessness and meaninglessness appear to be discrete phenomena.

$1_{\text {Fischer et al. (1977) conducted a secondary analysis on two }}$ surveys: (1) The Detroit Area Study of 1965-66, where 985 white males, 18-64, living in the Detroit SMSA, were interviewed; and (2) the National Opinion Research Center (NORC) national survey of 1967, where 75 percent of the 2,300 respondents were women, regardless of race. 
Consequently, the general theoretical implications of both findings cast disfavor on theories which assume alienation is a conspicuous, rampant feature of contemporary life. Such theories often conjure up ominous scenarios of unabated alienation. However, the emphasis is more upon the misfortune we will experience if we do not heed the warnings, rather than rightly upon how accurate are the assumptions the warnings issue from. Indeed, theorists such as Nisbet may have correctly assessed how power relations diminish communal life, but surely such an exposition can be made without the introduction of irrelevancies.

\section{IMPLICATIONS FOR FUTURE RESEARCH}

Because of the static nature of the one-shot survey, this study neglects some interesting issues. If more time and resources were available, it may have been fruitful to track feelings and perceptions of alienation across the institutional life of the graduate student. Such an approach might have revealed intervening factors which not only trigger alienation but which effect its evaporation. Although a longitudinal study of this kind would not, in and of itself, provide a better test of the hypotheses tested herein, such an approach would have contributed to a more direct analysis of the context-specific model of alienation. As such, even though this model seems more plausible than the unidimensional model, especially since the latter is rendered inadequate by the findings presented, it is possible some model other than these may yet explain alienation more thoroughly and accurately. 
Another drawback of this study, which should be considered in future research, is that little attempt was made to investigate alienation "below the surface." That is, a superficial emphasis was placed on attitude scales. No attempt to interview graduate students in person over several sessions, which could have allowed respondents to explain themselves more deeply and to reveal the complexity of their perceptions, was initiated. Indeed this omission seems to characterize the major disadvantage of survey research:

First, survey information ordinarily does not generate very deeply below the surface. The scope of information sought is usually emphasized at the expense of depth. This seems to be a weakness, however, that is not necessarily inherent in the method . . . it is possible to go considerably below surface opinions. Yet the survey seems best adapted to extensive rather than intensive research. Other types of research are perhaps better adapted to deeper explorations of relations (Kerlinger, $1973: 422$ ).

But beyond the disadvantages of this survey or survey research in general, the findings suggest that: 1) future research should concern itself with whether or not powerlessness and meaninglessness may be positively related in other racial groups; 2) future research should concentrate on testing the generalization hypothesis in focal areas other than political alienation, work alienation, and alienation in education; and 3) future research should explore more intensively the effect a wide range of voluntary associations may have on loss of community and alienation in power relations. ${ }^{1}$

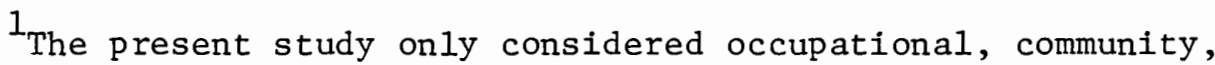
and political voluntary associations. The effects of membership in these associations on loss of community and alienation appear rather weak. For instance, as Table XIX illustrates, membership in voluntary associations seems superfluous to power relations. This 
For instance, Middleton (1963) reports that "by far the most striking finding of the study [on alienation, race, and education] is the pervasiveness of alienation among the Negro population" (Middleton, 1963:977). To be sure, of the 99 Southern Blacks he interviewed 70 percent reported they felt powerlessness and 71 percent meaninglessness (vs. 40 percent and 48 percent respectively for the 207 Southern White respondents).

Yet, as Table XXIV indicates, such a finding may reflect a historical rather than a general social fact. Between 1952-1964 the racial differential in perceptions of powerlessness for Southern Blacks fell 112 percent, until it was 4 percent below perceptions of powerlessness for Southern Whites. Meaninglessness, however, waxed and waned over the same period, but by 1964 the racial differential for Southern Blacks and Whites climbed slightly above the 1952 differential, a climb of 1 percentage point--entirely attributable to sampling error. Consequently, future research should not merely assume that Blacks, because of historical oppression, are a priori more likely to experience diffuse alienation, even though some past research suggests they once did. Neither should future research assume powerlessness and meaninglessness are a priori non-related for all groups and in all types of settings. Indeed, researchers can be assured such an event appears rather

is contrary to the solution Nisbet (1953) proposes for eradicating the supposed mass effects of alienation. However, in all honesty, the analysis of voluntary associations was not a major focus of this study, and thus it is entirely conceivable that other associations, such as religious or recreation groups (both of which respondents were not inquired about), might intervene to dispell or lessen the effects of alienation and loss of community. 
TRENDS IN POLITICAL EFFICACY AMONG SOUTHERN AND NORTHERN NEGROES RELATIVE TO THE WHITE LEVEL OF EFFICACY IN THE REGIONa

PERCENT NEGROES MINUS PERCENT WHITES GIVING RESPONSE INDICATIVE OF LOW EFFICACY North

People like me don't have any say in

what government does.

$\begin{array}{rrr}7952 & 33 & 4 \\ 1956 & 37 & 21 \\ 1960 & 12 & 12 \\ 1964 & -4 & 3\end{array}$

Politics and government are so com-

plicated that a person like me

can't understand.

7952

1956

7

3

1960

1964

21

6

10

10

$8-4$

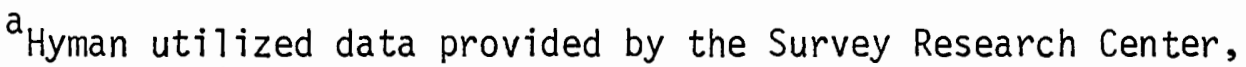
University of Michigan. He reports the number of Southern Black respondents ranged from 52 to 114 ; for Northern Blacks, from 40 to 62.

SOURCE: Adapted from Herbert Hyman, 1972, "Dimensions of Social-Psychological Change in the Negro Population" in Angus Campbell and Philip Converse (eds.), The Human Meaning of Social Change, New York: Russell Sage. 
rare, but rare events do occur and therefore nothing should be taken for granted. 


\section{BIBLIOGRAPHY}

Baker, Stephen

1974 The Elements of Logic. New York: McGraw-Hill.

Barakat, Halim

1970 "Alienation: A Process of Encounter Between Utopia and Reality." British Journal of Sociology 20:1-10.

Beveridge, William

1950 The Art of Scientific Investigation. London: Mercury.

Blalock, Hubert

1979 Social Statistics. New York: McGraw-Hi11.

Bolton, Charles

1972 "Alienation and Action: A Study of Peace-Group Members." American Journal of Sociology 78:537-561.

Caplan, Nathan, and Jeffrey Paige

1968 "A Study of Ghetto Roiters." Scientific American 218:15-21.

Clark, John

1959 "Measuring Alienation Within a Social System." American Sociological Review 24:849-852.

Cronback, Lee

1951 "Coefficient Alpha and the Internal Structure of Tests." Psychometrika $16 \cdot 297-334$.

Dean, Dwight

1961 "Alienation: Its Meaning and Measurement." American Sociological Review $26: 753-758$.

1965 "Powerlessness and Political Apathy." Social Science $40: 208-213$.

Dillman, Don, James Christenson, Edwin Carpenter, and Ralph Brooks

1974 "Increasing Mail Questionnaire Response: A Four-State Comparison." American Sociological Review 39:744-756.

Fischer, Claude

1976 "Alienation: Trying to Bridge the Chasm." British Journal of Sociology $27: 35-49$.

Fischer, Claude, Robert Jackson, and Ann Stueve

1977 Networks and Places: Social Relations in the Urban Setting. New York: Free Press. 
Flacks, Richard

1967 "The Liberated Generation: An Exploration of the Roots of Student Protest." Journal of Social Issues 23:52-75.

Hajda, Jan, and Robert Travis

1978 "Causes and Consequences of Powerlessness and Meaninglessness." Paper read at the 9th World Congress of Sociology, Uppsala, Sweden.

Hawkes, Roland

1971 "The Multivariate Analysis of Ordinal Measures." American Journal of Sociology 76:908-925.

Hyman, Herbert

1955 Survey Design and Analysis. New York: Free Press.

Kenniston, Kenneth

1971 Youth and Dissent. New York: Harcourt, Brace, Jovanovich.

Kerlinger, Fred

1973 Foundations of Behavioral Research. New York: Holt, Rinehart, Winston.

Kish, Leslie

1959 "Some Statistical Problems in Research Design." American Sociological Review 24:328-338.

Lee, Alfred

1973 "An Obituary for Alienation." Social Problems 22:121-127.

Lieberson, Stanley, and Arnold Silveiman

1965 "The Precipitants and Underlying Conditions of Race Riots." American Sociological Review 30:887-898.

Middleton, Russe11

1963 "Alienation, Race, and Education." American Sociological Review 26:973-977.

Morrison, Denton, and Allan Steeves

1967 "Deprivation, Discontent and Social Movement Participation: Evidence on a Contemporary Farmer's Movement, the NFO." Rural Sociology 32:413-433.

Neal, Arthur, William Ivoska, and Theodore Groat

1976 "Dimensions of Family Alienation in the Marital Dyad." Sociometry $39: 396-405$.

Nettler, Gywnne

1957 "A Measure of Alienation." American Sociological Review $22: 670-677$. 
Nisbet, Robert

1953 The Quest for Community. London: Oxford University Press.

Nunnally, Jim

1959 Tests and Measurements. New York: McGraw-Hi11.

Oppenheim, A.

1966 Questionnaire Design and Attitude Measurement. New York: Basic Books.

Perlin, Leonard

1962 "Alienation from Work: A Study of Nursing Personnel." American Sociological Review 27:314-326.

Pollock, Jane

1972 "Changing the Role of Women." Pp. 10-20 in Helen Wortis and Clara Rabinowitz (eds.), The Women's Movement. New York: AMS Press.

Quade, Dana

1974 "Nonparametric Partial Correlation." Pp. 369-398 in Hubert Blalock (ed.), Measurement in the Social Sciences. Chicago: Aldine.

Radsford, $H$.

1968 "Isolation, Powerlessness, and Violence: A Study of Attitudes and Participation in the Watts Riots." American Journal of Sociology 33:581-591.

Reynolds, H.

1974 "Ordinal Partial Correlation and Causal Inferences." Pp. 399-423 in Hubert Blalock (ed.), Measurement in the Social Sciences. Chicago: Aldine.

Robinson, John, and Phillip Shaver

1973 Measures of Social Psychological Attitudes. Ann Arbor: Institute for Social Research.

Rosenberg, Morris

1968 The Logic of Survey Analysis. New York: Basic Books.

Schacht, Richard

1970 Alienation. New York: Doubleday.

Seeman, Melvin

1959 "On The Meaning of Alienation." American Sociological Review 24:783-791.

1963 "Alienation and Social Learning in a Reformatory." American Journal of Sociology 69:270-284. 
1967 "On the Personal Consequences of Alienation in Work." American Sociological Review 32.273-285.

1972 "The Signals of '68: Alienation in Pre-Crisis France." American Sociological Review 37:385-402.

Seeman, Melvin, and John Evans

1962 "Alienation and Learning in a Hospital Setting." American Socịological Review 27:772-782.

Siege1, Sidney

1956 Nonparametric Statistics for the Behavioral Sciences. New York: McGraw-Hill.

Srole, Leo

1956 "Social Integration and Certain Corrollaries: An Exploratory Study." American Sociological Review 21:709-716.

Stouffer, Samuel

1950 "Observations on Study Design." American Journal of Sociology $4: 355-361$.

Thompson, Wayne, and John Horton

1960 "Political Alienation as a Force in Political Action." Social Forces 38:190-195.

Trent, James, and Judith Craise

1967 "Commitment and Conformity in the American College." Journal of Social Issues 23:34-51.

Watts, William, Steve Lynch, and David Whittaker

1969 "Alienation and Activism in Today's College-Age Youth: Socialization Patterns and Current Family Relationships." Journal of Counseling Psychology 16:1-7.

Wegner, Eldon

1975 "The Concept of Alienation: A Critique and Some Suggestions for a Context-Specific Approach." Pacific Sociological Review 18:171-193.

Weisberg, Herbert, and Bruce Bowen

1977 Survey Research and Data Analysis. San Francisco: Freeman.

Yankelovich, Daniel

1972 The Changing Values on Campus. New York: Washington Square Press.

Zeisel, Hans

1947 Say It With Figures. New York: Harper and Row.

Zelditch, Morris

1959 A Basic Course in Sociological Statistics. New York: Holt. 
APPENDIX 


\section{SPRING SURVEY QUESTIONNAIRE}

Dear Student:

This short questionnaire represents a thesis project by a graduate student of Portland State University. It is being sent to postbaccalaureate and graduate students here. The questionnaire focuses on your assessment of American Government, PSU Education, and your Life-Space. When the results are in, the perceptions and experiences of both groups will be compared.

A small number of students within each group are being questioned. Every response is important, since non-responses will jeopardize the study's validity and representativeness.

Please complete this questionnaire, even if you have doubts about some questions; for, it offers a student basic research experience. This study will be evaluated by a committee of Sociology professors. Al] expenses are paid by the student.

Moreover, your participation in this survey is entirely voluntary; so not participating will not effect your status at PSU. Should you participate though, your responses will remain confidential. The numbers on the return envelopes help identify nonrespondents, so they can be contacted and encouraged to reply. All envelopes and address lists will be destroyed after most or all questionnaires are completed.

Feel free to send any requests, comments, or criticisms to:

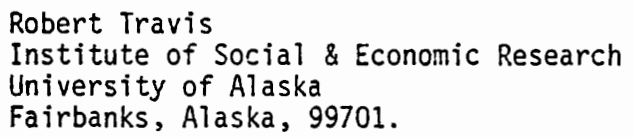

Your comments may help me design questionnaires better.

Finally, this questionnaire should only be completed by those selected, even those who have left PSU. If all goes well, you may one day read about these findings.

Thanks,

Robert Travis 
Here are some questions on politics, education, and your life-space. After each guestion or statement, olease check the one response that best fits you. $\begin{array}{ccc}\text { STRONGLY } & \text { DIS- STRONGLY DON'T } \\ \text { AGREE AGREE DIVIDED AGREE DISAGREE KNOW }\end{array}$

1. Voting for national leaders

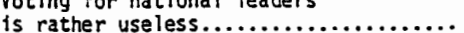

2. The U.S. Government is democratic

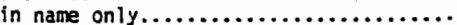

3. The present two-party system generally offers real alternatives.............

4. Being aware of national political issues really does matter.

5. Until we restrict the political power of Elites, we will never really solve

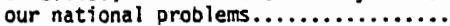

6. The average citizen still can influence what the U.S. Gov't proposes to do.....

7. Poifticaliy, do you regard yourself as: _ conservative/ _ moderate/ _ Tiberal/__ radical/__ not sure

8. Oid you vote in the 1976 U.S. Presidential Election? $\rightarrow$ yes/ _ no no IF NO, PLEASE STATE WHY?

9. How often do you get upset with nationai leaders not practicing what they clajm to believe in?

(very often) (hardly ever)

10. Are you active in any professional, civic, or political groups? _ yes/ _ no $* *$ IF YES, PLEASE NAME THE ONE MOST IMPORTANT TO YOU.

11. Would you prefer living in another country to get away from American society?

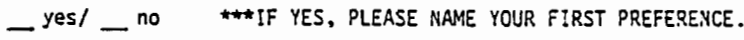

12. Though the U.S. Government at times acts controversially, some think it remains a system of justice, based upon the consent of the governed. Others, however, think it inadequatel. represents people, is based more upon power than consent, and is therefore unjust. 'ihat do you think?

As a system, how just or unjust do you think the U.S. Government is?

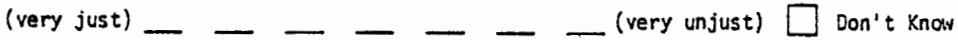

13. During the Vietnam War, how fnvolved were you in any demonstrations or protests? (very involved) (not involved at all) 
14. Adninistrators and faculty may have more institutional power, but students generally can influence things to the ir own benefit.....................

15. This university provides students with an education relevant to their needs...

16. Getting an education means 1 tttle more than being certified to do a job........

17. When it comes to changing class requirements, students can't do much more than complain among themselves.............

18. If a professor treats you unfairly, making an official protest will probabl do you more harm than good.............

19. So much knowledge exists today that what I write for classes is rather useless

in comparison......................

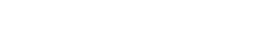

20. Have your expectations of what education should be like been met at PSU? _yes/ ${ }^{\text {nol }}$ _ not sure

21. How often do you feel apatheric about doing coursework? (very often) (hardiy ever)

22. Advanced students are often expected to serve on departmental comittees, providing recommendations for faculty consideration. This system draws mixed reviews. Some students are satisfied their opinions count, while others are dissatisfied that dedartmental matcers are largely managed without them. What is your perception?

Do you consider PSU's departmental system a fair or unfair way to govern things? (very fair) (very unfair) Don't Know

23. Today there are many alternative modes of explanation, such as Eastern philosophies Astrology and so on, in contrast to wiestern Rationalism, such as Psychology, Natural Science and so on. On the following scales please indicate how valuable or useless these two modes are in your life:

Alternative Explanations

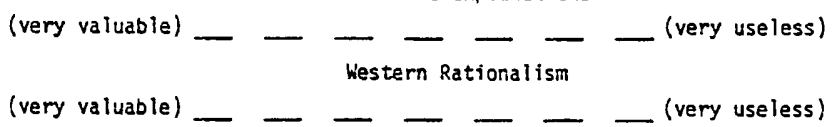

24. Do you serve on any departmental committees at PSU?

— yes/_no

25. Why are you now attending PSU? 
26. Do you generally feel a sense of community, or togetherness, concerning...

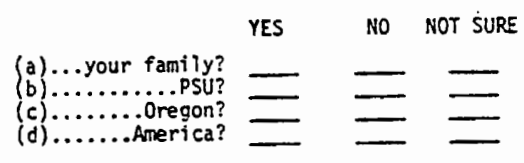

Here are some questions about your personal traits. Your responses are very important, since they will allow for my comparing different people.

27. What ts your marital status?

$$
\text { — never married/ _ married/_ divorced or separated/ _widowed }
$$

28. Do you live by yourself?

—yes/ - no $\star \star \star I F$ YES, PLEASE SKIP TO Q-30.

29. Do you have chtldren living with you?

_ yes/ _ no

30. What is your race or national origin? _Black/ _Chicano/ _ Native American/ _Oriental/ _White/ _ Other:

31. Are you male or fenale?

$$
\text { _male/ _ female }
$$

32. What is your age please?

33. What is your major?

34. Do you work at any kind of job apart from homelife? —yes/ no IF NO, PLEASE SKIP TO $\$-36$.

35. Do you work part-time or full-time?

$$
\text { - part-time/ _ full-time }
$$

36. Financially, how difficult has your life been in the last year?

(very difficult) (not at all difficult)

37. How has your health been in the last year?

$$
\text { _ good/_fairl_poor }
$$

38. Does either of your parents have a college degree?

$$
\text { - yes/ _ no }
$$

39. How many credit hours are you now taking at PSU?

40. Lastly, how many quarters have you attended classes at PSU?

Thank you for cooperating in this thes is project! Any comments? Back page, please. 
FOLLOW-UP POSTCARD

My thesis will test theories on people's thoughts on social institutions. Your opinions are valuabie.

Please complete the questionnaire I sent you.

Thanks,

\section{NONRESPONDENT QUESTIONNAIRE}

Dear Student.

Recently I sent you questionnaires asking for your att ftudes toward government and education. Since you and some other PSU students. or former students, dit not reply, I'd like to know more about you. Please answer the follow. ing fex questions. This will heid me restrict my interpretations more accurately, after knowing arore clearly what you and some other nonrespondents are like.

Thanks,

Robert Travis

Plense read the enclosed note before completing these questions. Thank you.

1. What is, or was, your anjor at PSU?

2. How many quarters have you attended elasses at PSU?

3. Have your expectations of what education shovid be like

_res/ _ nol _ not sure

4. Did you vote in the 1976 U.S. Presidential Election? - res/ _ nol IF MO. PLEASE STATE WHY?

5. Are you male or female?

$$
\text { - mie/ _female }
$$

6. What is your age please? 